Vol. 10 (2001): 347-364.

\title{
Weeds in spring cereal fields in Finland - a third survey
}

Jukka Salonen, Terho Hyvönen and Heikki Jalli

MTT Agrifood Research Finland, Plant Production Research, FIN-31600 Jokioinen, Finland, e-mail: jukka.salonen@mtt.fi

\begin{abstract}
A survey of weeds in spring cereal fields was conducted in 16 regions of southern and central Finland in 1997-1999. Data were collected from conventional and organic farms, both of which applied their normal cropping practices. A total of 690 fields were investigated by counting and weighing the weed species from ten sample quadrats $0.1 \mathrm{~m}^{2}$ in size in late July - early August. Altogether 160 weed species were found, of which 134 were broad-leaved and 26 grass species. The total number of weed species ranged from 41 to 84 between regions. In organically farmed fields, the average species number was 24 and in conventionally farmed fields 16 . The most frequent weed species were Viola arvensis $84 \%$, Stellaria media $76 \%$ and Galeopsis spp. $70 \%$. Only 18 species exceeded the frequency level of $33 \%$. The average density of weeds was $136 \mathrm{~m}^{-2}$ (median= 91$)$ in sprayed conventional fields, $420 \mathrm{~m}^{-2}(374)$ in unsprayed conventional fields and $469 \mathrm{~m}^{-2}$ (395) in organic fields. The average airdry above-ground biomass of weeds was $163 \mathrm{~kg} \mathrm{ha}^{-1}$ (median=63), $605 \mathrm{~kg} \mathrm{ha}^{-1}$ (413) and $678 \mathrm{~kg} \mathrm{ha}^{-1}$ (567), respectively. Weed biomass accounted for $3 \%$ of the total biomass of the crop stand in sprayed conventional fields and for $17 \%$ in organic fields. Elymus repens, the most frequent grass species, produced the highest proportion of weed biomass.
\end{abstract}

Key words: weeds, cereals, biodiversity, organic farming, crop protection

\section{Introduction}

MTT Agrifood Research Finland has carried out two extensive surveys of weeds in spring cereal fields in Finland, the first in 1961-1964 (Mukula et al. 1969) and the second in 1982-1984 (Erviö and Salonen 1987). Similar surveys have been conducted elsewhere, e.g. in England (Chancellor and Froud-Williams 1984), Den- mark (Andreasen et al. 1991), Germany (Albrecht 1995) and Hungary (Tóth et al. 1999).

Regular weed surveys are considered a necessary and valuable way of monitoring the responses of weed floras to changes in agricultural practices and habitats. The most frequent and abundant weed species are of interest in terms of control measures. Current research projects focus not only on agricultural features of weed occurrence but also on biodiversity in agricul- 
Salonen, J. et al. Weeds in spring cereals in Finland

tural environments (Becker and Hurle 1998, Hald 1999).

In the 1990s, crop production in Finland underwent changes that apparently affected weed floras in fields. The most marked changes were 1) the implementation of an extensive fallow scheme in the early 1990s, which peaked in 1994 at 505000 ha (almost $25 \%$ of the cultivated area), 2) the switch to organic farming by roughly 5000 farms, accounting now for $6 \%$ of the cultivated field area and 3) the shift from the use of phenoxy acid herbicides to sulphonylureas, which differ from the former in selectivity among weed species.

Since 1995, when Finland became a member of the European Union, the economic basis of crop production has had to contend with cuts in prices of products. To compensate for losses to farmers, the government introduced a system of area-based subsidies taking into account certain special conditions. The Agri-Environmental Support Scheme was launched with the aim, among others, of promoting the environmentally sus-

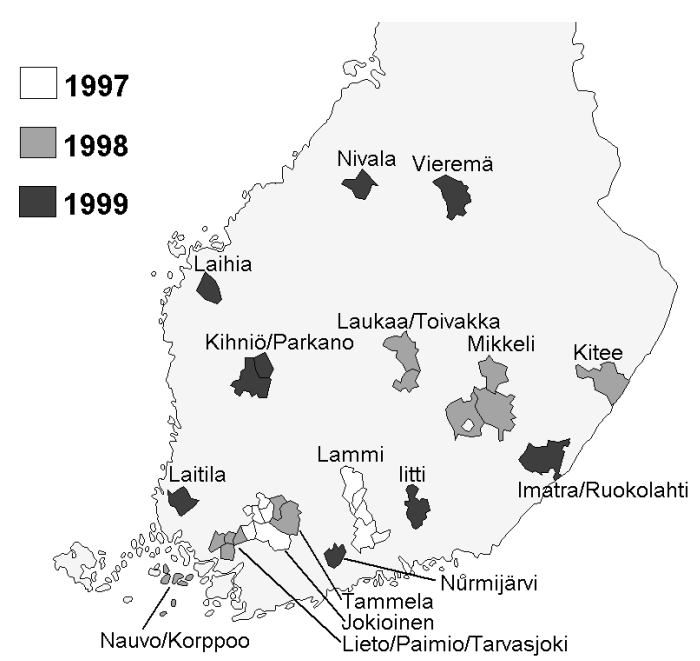

Fig. 1. Weed survey regions in 1997-1999. Key to region numbers: 1 = Jokioinen, 2 = Lammi, 3 = Nauvo/Korppoo, 4 = Tammela, 5 = Laukaa/Toivakka, $6=$ Kitee, 7 = Mikkeli, 8 = Paimio/Tarvasjoki, $9=$ Laihia, $10=$ Nivala, $11=$ Laitila, 12 = Nurmijärvi, 13 = Vieremä, $14=$ Kihniö/Parkano, 15 = Iitti, 16 = Imatra/Ruokolahti. tainable use of fertilizers and pesticides (Ministry of Agriculture and Forestry 1999).

A longer term change in agriculture has been the regional specialization of production. Nowadays, southern and south-western Finland are characterized by a high dominance of cereal crops in rotation whereas in central and eastern Finland the use of arable land is more diverse, many farms practising crop rotation based on grassland for silage and hay and pasture for cattle. Since this diversity of crop rotation has been found to have some effect on the species composition (Bàrberi et al. 1997) and species diversity (Doucet et al. 1999) of weed communities, we expected to find differences between regions.

The objective of the survey was to investigate the current status of weed occurrence in spring cereal fields, examining both conventionally and organically cultivated fields. This first report focuses on the botanical composition of fields. It is aimed, on the one hand, at farmers, advisory services and the chemical industry with a view to promoting specific weed control measures and, on the other, at scientists and authorities as a report on the diversity of weed flora. A more detailed analysis of the factors explaining weed occurrence and changes in weed floras over the decades will be given separately.

\section{Material and methods}

\section{Study regions, farms and fields}

The present weed survey was carried out in southern and central Finland in 1997-1999. The 16 regions surveyed (Fig. 1, Table 1) are referred to in tables and figures by the numbers given in Table 1. Regions 1 and 2 were studied in 1997 as a preliminary survey. The other regions (nos. 3-16) were chosen from those studied in surveys conducted in the 1960s and 1980s. The initial intention of this survey was to visit exactly the same fields as those studied earlier but this was not entirely practicable, since spring cereals were 
Vol. 10 (2001): 347-364.

Table 1 . Number of fields surveyed by region, production type and cereal species.

\begin{tabular}{|c|c|c|c|c|c|c|c|c|}
\hline \multirow{2}{*}{\multicolumn{2}{|c|}{ Region }} & \multicolumn{7}{|c|}{ Number of fields } \\
\hline & & \multicolumn{3}{|c|}{ Production type } & \multicolumn{4}{|c|}{ Cereal species } \\
\hline $\begin{array}{l}\text { Year } \\
\text { Municipality }\end{array}$ & No & Total & Conventional $^{5}$ & Organic & Barley & Oat & Wheat & Others \\
\hline \multicolumn{9}{|l|}{1997} \\
\hline Jokioinen $^{1}$ & 1 & 62 & $47(43)$ & 15 & 41 & 15 & 5 & 1 \\
\hline Lammi $^{2}$ & 2 & 63 & $44(42)$ & 19 & 21 & 29 & 8 & 5 \\
\hline \multicolumn{9}{|l|}{1998} \\
\hline Nauvo/Korppoo & 3 & 40 & $40(36)$ & 0 & 19 & 13 & 8 & 0 \\
\hline Tammela & 4 & 53 & $44(32)$ & 9 & 34 & 13 & 4 & 2 \\
\hline Laukaa/Toivakka & 5 & 46 & $34(26)$ & 12 & 20 & 26 & 0 & 0 \\
\hline Kitee & 6 & 24 & $15(10)$ & 9 & 6 & 17 & 1 & 0 \\
\hline Mikkeli $^{3}$ & 7 & 42 & $26(26)$ & 16 & 20 & 17 & 0 & 5 \\
\hline Paimio/Tarvasjoki ${ }^{4}$ & 8 & 73 & $57(43)$ & 16 & 22 & 6 & 45 & 0 \\
\hline \multicolumn{9}{|l|}{1999} \\
\hline Laihia & 9 & 42 & $37(37)$ & 5 & 27 & 11 & 4 & 0 \\
\hline Nivala & 10 & 31 & $21(16)$ & 10 & 20 & 11 & 0 & 0 \\
\hline Laitila & 11 & 51 & $38(38)$ & 13 & 34 & 14 & 3 & 0 \\
\hline Nurmijärvi & 12 & 43 & $35(35)$ & 8 & 24 & 5 & 14 & 0 \\
\hline Vieremä & 13 & 26 & $17(12)$ & 9 & 18 & 6 & 0 & 2 \\
\hline Kihniö/Parkano & 14 & 33 & $24(16)$ & 9 & 9 & 23 & 1 & 0 \\
\hline Iitti & 15 & 35 & $27(26)$ & 8 & 18 & 13 & 3 & 1 \\
\hline Imatra/Ruokolahti & 16 & 26 & $19(19)$ & 7 & 10 & 14 & 1 & 1 \\
\hline Total & & 690 & 525 (457) & 165 & 343 & 233 & 97 & 17 \\
\hline
\end{tabular}

1 incl. Humppila, Jokioinen, Koski Tl, Loimaa municipality, Somero, Ypäjä

2 incl. Hämeenkoski, Kärkölä, Lammi, Mäntsälä, Pukkila

3 incl. Joroinen, Juva, Mikkeli, Mikkeli rural municipality

${ }^{4}$ incl. Lieto

${ }^{5}$ number of sprayed fields in parentheses

not grown in many of the study fields in the particular study year.

The choice of study regions reflects the prevalence of spring cereal crops in rotation in different regions. Consequently, the highest number of fields was studied in south-western Finland, where spring cereals are grown in more than 50\% of the arable area and annual spring-sown crops are predominant. The number of study fields decreased towards the east and north, where spring cereals account for less than $50 \%$ of the cultivated area, and many farms include grassland in their crop rotation.

The number of farms visited was 305 , of which 229 engaged in conventional and 76 in organic farming. The study farms were either crop husbandry farms (174) without grassland in crop rotation or animal husbandry farms (131) with pasture in crop rotation. The fields of crop husbandry farms exceeded $70 \%$ of the studied fields in five regions (Nauvo/Korppoo, Paimio/ Tarvasjoki, Laihia, Nurmijärvi and Iitti) and those of animal husbandry farms in four regions (Jokioinen, Kitee, Nivala, Vieremä). The farm types were not evenly distributed over the study regions but reflected, as said, regional differences in farming structure. The survey region in the south-western archipelago, Nauvo/Korppoo (3), was the only one without organically cultivated spring cereal fields. The proportion of organic 
Salonen, J. et al. Weeds in spring cereals in Finland

Table 2. Weather conditions in survey regions.

\begin{tabular}{|c|c|c|c|c|c|c|c|}
\hline \multirow{2}{*}{$\begin{array}{l}\text { Survey region } \\
\text { Year } \\
\text { Municipality }\end{array}$} & \multirow{2}{*}{$\frac{\text { Region }}{\text { No }}$} & \multicolumn{4}{|c|}{$\begin{array}{l}\text { Monthly precipitation } \\
\text { mm }\end{array}$} & \multirow{2}{*}{$\begin{array}{c}\text { ETS }{ }^{1} \\
\text { DD5 } \\
\text { by } 31-J u l y\end{array}$} & \multirow[b]{2}{*}{ Weather station } \\
\hline & & May & June & July & Total & & \\
\hline \multicolumn{8}{|l|}{1997} \\
\hline Jokioinen & 1 & 15 & 101 & 141 & 257 & 819 & Jokioinen \\
\hline Lammi & 2 & 12 & 73 & 120 & 205 & 764 & Lammi \\
\hline \multicolumn{8}{|l|}{1998} \\
\hline Nauvo/Korppoo & 3 & 42 & 62 & 41 & 145 & 671 & Korppoo \\
\hline Tammela & 4 & 65 & 99 & 70 & 234 & 762 & Jokioinen \\
\hline Laukaa/Toivakka & 5 & 26 & 96 & 112 & 234 & 688 & Jyväskylä \\
\hline Kitee & 6 & 53 & 101 & 146 & 300 & 712 & Joensuu \\
\hline Mikkeli & 7 & 32 & 83 & 112 & 227 & 738 & Mikkeli rural municipality \\
\hline Paimio/Tarvasjoki & 8 & 27 & 93 & 72 & 192 & 817 & Turku \\
\hline \multicolumn{8}{|l|}{1999} \\
\hline Laihia & 9 & 21 & 36 & 35 & 92 & 822 & Ylistaro \\
\hline Nivala & 10 & 49 & 39 & 92 & 180 & 806 & Nivala \\
\hline Laitila & 11 & 6 & 30 & 16 & 51 & 918 & Mietoinen \\
\hline Nurmijärvi & 12 & 19 & 34 & 20 & 73 & 901 & Vihti, Maasoja \\
\hline Vieremä & 13 & 47 & 28 & 75 & 150 & 785 & Kajaani \\
\hline Kihniö/Parkano & 14 & 31 & 17 & 98 & 146 & 786 & Ähtäri \\
\hline Iitti & 15 & 17 & 52 & 49 & 118 & 943 & Utti \\
\hline Imatra/Ruokolahti & 16 & 6 & 30 & 35 & 71 & 1030 & Lappeenranta \\
\hline
\end{tabular}

(Source: Finnish Meteorological Institute)

${ }^{1}$ ETS $=$ Effective temperature sum in degree days accumulated above a base temperature of $5^{\circ} \mathrm{C}$ (DD5)

survey fields was highest, 30-38\%, in Lammi, Kitee, Mikkeli, Nivala and Vieremä.

Typically, a great majority of study fields were sown in mid-May (weeks no. 19-21) and sprayed with herbicides in mid-June (weeks no. 23-25). Weather conditions varied considerably between study years and regions (Table 2).

On each farm, one to eight spring cereal fields were examined, giving a total of 690 fields: 343 under barley (Hordeum vulgare L.), 233 under oats (Avena sativa L.), 97 under wheat (Triticum aestivum L.) and 17 in mixed cultivation. Altogether 525 study fields were cultivated conventionally and 165 organically.

To gain an overview of actual weed populations in the middle of the growing season, no instructions on crop management, e.g. on herbicide use or fertilization, were given to farmers in advance. At the sampling time, the information on cropping measures was recorded by in- terviewing the farmers. The national regulation on organic cereal production bans the application of chemical fertilizers and pesticides and sets an upper limit on the use of organic fertilizers (Ministry of Agriculture and Forestry 1999).

The average area of the 690 study fields was 4.3 ha (range 0.2 ha -35.3 ha), distributed in different size classes as follows:
$<1$ ha
65 fields
$1-2$ ha
151 fields
$2-5$ ha
257 fields
$5-10$ ha
148 fields
$>10$ ha
69 fields

Herbicides had been applied in 457 out of 525 , i.e. $87 \%$, conventionally cultivated fields. Four major types of active ingredients had been used: pure MCPA (4-chloro-2-methylphenoxyacetic acid) in $23 \%$ of treated fields, MCPA + other phenoxy acids (20\%), sulphonylureas 
Vol. 10 (2001): 347-364.

$(42 \%)$ and phenoxy acids + sulphonylureas $(15 \%)$.

\section{Weed sampling}

The present survey was carried out in 1997-1999 during a 4-week period starting in mid-July (weeks no. 28/29), by which time the spring cereals had reached their heading stage and at least 1 month had elapsed since herbicide treatment.

The occurrence of weeds was assessed from 10 sample quadrats randomly placed in each field. For this purpose, each field was split in a $10 \times 10$ cell grid in which the positions of sample quadrats were set with a random number calculator. The size of grid cells varied between fields according to the area of each field. Two sample quadrats were placed at a distance of 1$3 \mathrm{~m}$ from the sown field edge and the other eight more than $5 \mathrm{~m}$ from the edge.

Weed density was determined by counting the number of plants or shoots of grass weeds by species in a rectangular frame measuring $0.1 \mathrm{~m}^{2}$ $(25 \mathrm{~cm} \times 40 \mathrm{~cm})$, which was a corner area within a larger quadrat measuring $1.0 \mathrm{~m}^{2}(1.0 \mathrm{~m} \times$ $1.0 \mathrm{~m}$ ). The larger quadrat was used for observations of the presence/absence of each species. In 1997 (Jokioinen and Lammi), only the $0.1 \mathrm{~m}^{2}$ sample quadrats were used in the sampling. The results presented in the tables and figures derive from data collected from the $0.1 \mathrm{~m}^{2}$ quadrats and pooled over the samples in each field. A complete list of the additional weed species found in the presence/absence observation is given in Appendix 1 as a supplement to the 42 species presented in the tables.

In four out of ten small sample quadrats, weeds and cereals were cut at the soil surface and their biomass was weighed by species after the samples had been dried in an air-flow dryer at $40^{\circ} \mathrm{C}$ for some days. The average biomass of a single plant was calculated by dividing the biomass of each species by the numbers of that plant in fields where the species was present, provided that data were available from at least 20 fields.

\section{Nomenclature and data analysis}

As the present survey focused on the diversity of weed flora, all weed species found in sampling areas were assessed. Nevertheless, some genera/taxa, e.g. Galeopsis spp. and Lamium spp., had to be pooled since they could not be identified by species at the small seedling stage.

The plant species nomenclature follows Hämet-Ahti et al. (1998), and the BAYER codes of weeds were derived from the BAYER AG company (Bayer 1992). The most recent change in nomenclature concerns Polygonum species, as they are now divided into four families: Aconogonon, Bistorta, Persicaria and Polygonum (Hämet-Ahti et al. 1998). Consequently, Bistorta vivipara (L.) Gray (alias Polygonum viviparum L.), Persicaria hydropiper (L.) Spach (alias Polygonum hydropiper L.), Persicaria lapathifolia (L.) Gray (alias Polygonum lapathifolium L.) and Persicaria maculosa Gray (alias Polygonum persicaria L.) have been re-named. The full scientific names with attribution are given in Table 3.

The term frequency indicates the proportion of fields where the species was found. The frequency results are classified as in Mukula et al. (1969). For each field, the total weed density and biomass were summed, and the averages, standard deviations and median values are given in the text. To ensure consistency with the manner of data presentation in previous surveys (Mukula et al. 1969, Erviö and Salonen 1987), the average weed densities and dry weights by species are presented. Median values are given for total biomass and density but not for single species since most of the median values would have been zero due to the low frequency.

The results of the three surveys should nonetheless be compared with caution as the sampling technique used in the present survey was slightly modified in terms of size and number of quadrats. Furthermore, in contrast to previous surveys, the majority, $66 \%$, of the fields studied were sprayed with herbicides.

The similarity of species composition between regions was compared by Jaccard's simi- 
Salonen, J. et al. Weeds in spring cereals in Finland

Table 3. Frequencies (\%) of weed species by region.

\begin{tabular}{|c|c|c|c|c|c|c|c|c|c|c|c|c|c|c|c|c|c|}
\hline \multirow{3}{*}{ Species / Taxon } & \multicolumn{16}{|c|}{ Year / Region } & \multirow{3}{*}{$\begin{array}{l}\text { Average } \\
\text { 1997-99 }\end{array}$} \\
\hline & \multicolumn{2}{|c|}{1997} & \multicolumn{6}{|c|}{1998} & \multicolumn{8}{|c|}{1999} & \\
\hline & 1 & 2 & 3 & 4 & 5 & 6 & 7 & 8 & 9 & 10 & 11 & 12 & 13 & 14 & 15 & 16 & \\
\hline Achillea millefolium $\mathrm{L}$. & 3 & 5 & 0 & 8 & 7 & 21 & 10 & 0 & 0 & 3 & 2 & 5 & 12 & 15 & 9 & 4 & 5 \\
\hline Brassica rapa L. ssp. oleifera (DC.) METZG. & 15 & 14 & 0 & 2 & 11 & 0 & 5 & 3 & 12 & 0 & 20 & 14 & 0 & 27 & 9 & 4 & 9 \\
\hline Capsella bursa-pastoris (L.) MEDIK. & 15 & 24 & 8 & 28 & 39 & 58 & 45 & 16 & 7 & 10 & 18 & 5 & 31 & 39 & 14 & 12 & 22 \\
\hline Cerastium fontanum BAUMG. & 0 & 3 & 0 & 13 & 22 & 46 & 21 & 4 & 2 & 19 & 0 & 0 & 46 & 12 & 0 & 4 & 10 \\
\hline Chenopodium album $\mathrm{L}$. & 77 & 83 & 65 & 60 & 80 & 83 & 52 & 56 & 50 & 77 & 80 & 63 & 65 & 79 & 63 & 39 & 68 \\
\hline Cirsium arvense (L.) SCOP. & 29 & 22 & 18 & 38 & 17 & 8 & 17 & 33 & 14 & 13 & 4 & 33 & 19 & 12 & 29 & 31 & 22 \\
\hline Elymus repens (L.) GOULD & 63 & 73 & 60 & 68 & 76 & 96 & 81 & 43 & 62 & 74 & 61 & 47 & 65 & 70 & 77 & 81 & 66 \\
\hline Epilobium angustifolium L. & 2 & 0 & 0 & 11 & 9 & 8 & 7 & 14 & 0 & 7 & 2 & 0 & 15 & 18 & 0 & 12 & 6 \\
\hline Equisetum arvense $\mathrm{L}$. & 18 & 14 & 20 & 21 & 20 & 8 & 21 & 40 & 5 & 6 & 12 & 12 & 35 & 15 & 3 & 8 & 17 \\
\hline Erysimum cheiranthoides L. & 36 & 48 & 55 & 55 & 63 & 71 & 57 & 43 & 26 & 55 & 33 & 21 & 73 & 64 & 37 & 42 & 47 \\
\hline Fallopia convolvulus (L.) À. LÖVE & 50 & 54 & 35 & 66 & 22 & 46 & 38 & 69 & 71 & 48 & 65 & 61 & 8 & 24 & 66 & 85 & 52 \\
\hline Fumaria officinalis L. & 32 & 56 & 25 & 36 & 61 & 46 & 24 & 45 & 17 & 16 & 27 & 74 & 23 & 33 & 51 & 69 & 40 \\
\hline Galeopsis L. spp. & 79 & 87 & 38 & 68 & 91 & 79 & 57 & 77 & 60 & 94 & 61 & 40 & 89 & 88 & 54 & 62 & 70 \\
\hline Galium spurium $\mathrm{L}^{\mathrm{a}}$ & 37 & 38 & 83 & 64 & 20 & 29 & 19 & 53 & 55 & 7 & 53 & 47 & 19 & 0 & 49 & 42 & 41 \\
\hline Gnaphalium uliginosum $\mathrm{L}$. & 7 & 29 & 0 & 47 & 83 & 71 & 57 & 23 & 0 & 84 & 8 & 2 & 92 & 70 & 11 & 46 & 34 \\
\hline Juncus bufonius L. & 0 & 2 & 0 & 15 & 26 & 38 & 36 & 0 & 0 & 19 & 0 & 0 & 12 & 15 & 0 & 4 & 9 \\
\hline Lamium L. spp. & 32 & 25 & 78 & 28 & 15 & 8 & 14 & 60 & 12 & 0 & 43 & 35 & 0 & 9 & 26 & 39 & 30 \\
\hline Lapsana communis $\mathrm{L}$. & 47 & 79 & 80 & 68 & 74 & 54 & 81 & 36 & 7 & 0 & 69 & 35 & 0 & 15 & 66 & 89 & 52 \\
\hline Lathyrus pratensis L. & 18 & 5 & 0 & 8 & 0 & 0 & 2 & 8 & 5 & 3 & 0 & 2 & 8 & 0 & 6 & 8 & 5 \\
\hline Matricaria matricarioides (LESS.) PORT. & 26 & 25 & 8 & 45 & 85 & 63 & 57 & 29 & 17 & 61 & 20 & 0 & 65 & 58 & 31 & 42 & 37 \\
\hline Myosotis arvensis (L.) HILL & 37 & 46 & 23 & 51 & 72 & 58 & 91 & 67 & 31 & 23 & 22 & 7 & 54 & 52 & 37 & 54 & 46 \\
\hline Persicaria hydropiper (L.) SPACH & 0 & 0 & 0 & 23 & 11 & 29 & 31 & 0 & 0 & 3 & 18 & 0 & 0 & 9 & 17 & 42 & 10 \\
\hline Persicaria lapathifolia (L.) GRAY & 40 & 59 & 15 & 45 & 54 & 46 & 36 & 37 & 29 & 74 & 20 & 2 & 85 & 88 & 20 & 62 & 42 \\
\hline Persicaria maculosa GRAY & 0 & 0 & 0 & 11 & 0 & 0 & 0 & 34 & 0 & 0 & 22 & 21 & 0 & 0 & 17 & 23 & 9 \\
\hline Plantago major L. & 8 & 14 & 10 & 21 & 50 & 75 & 50 & 7 & 2 & 26 & 8 & 0 & 89 & 21 & 11 & 27 & 22 \\
\hline Poa аппиа L. & 7 & 3 & 0 & 23 & 7 & 33 & 41 & 7 & 5 & 3 & 24 & 5 & 8 & 6 & 9 & 27 & 12 \\
\hline Polygonum aviculare $\mathrm{L}$. & 55 & 73 & 18 & 59 & 52 & 71 & 41 & 44 & 43 & 81 & 75 & 67 & 73 & 73 & 71 & 42 & 58 \\
\hline Ranunculus acris L. & 7 & 16 & 0 & 11 & 54 & 4 & 10 & 6 & 0 & 10 & 2 & 0 & 50 & 55 & 0 & 0 & 13 \\
\hline Ranunculus repens $\mathrm{L}$. & 0 & 25 & 8 & 13 & 37 & 67 & 36 & 10 & 2 & 55 & 6 & 5 & 62 & 9 & 6 & 27 & 19 \\
\hline Rumex acetosa $\mathrm{L}$. & 0 & 5 & 0 & 0 & 30 & 0 & 5 & 1 & 0 & 7 & 2 & 0 & 12 & 36 & 0 & 4 & 6 \\
\hline Rumex acetosella $\mathrm{L}$. & 3 & 8 & 0 & 15 & 11 & 25 & 12 & 3 & 5 & 10 & 0 & 0 & 15 & 0 & 0 & 4 & 6 \\
\hline Sonchus arvensis L. & 36 & 71 & 23 & 47 & 70 & 25 & 41 & 25 & 17 & 26 & 20 & 19 & 42 & 36 & 46 & 58 & 38 \\
\hline Spergula arvensis $\mathrm{L}$. & 39 & 64 & 33 & 62 & 87 & 71 & 71 & 34 & 21 & 65 & 35 & 21 & 77 & 82 & 40 & 50 & 51 \\
\hline Stellaria media (L.) VILL. & 87 & 86 & 58 & 85 & 78 & 100 & 67 & 89 & 64 & 90 & 67 & 35 & 69 & 85 & 57 & 85 & 76 \\
\hline Taraxacum officinale WEBER in WIGGERS & 45 & 8 & 3 & 45 & 13 & 71 & 12 & 51 & 0 & 7 & 0 & 7 & 54 & 18 & 6 & 54 & 24 \\
\hline Thlaspi arvense $\mathrm{L}$. & 15 & 25 & 3 & 8 & 9 & 4 & 2 & 11 & 7 & 19 & 8 & 2 & 0 & 12 & 20 & 12 & 10 \\
\hline Trifolium L. spp. & 26 & 57 & 28 & 36 & 41 & 67 & 33 & 32 & 19 & 35 & 14 & 14 & 77 & 45 & 31 & 27 & 35 \\
\hline Tripleurospermum inodorum (L.) SCH. BIP. & 53 & 41 & 45 & 55 & 43 & 13 & 45 & 71 & 14 & 52 & 10 & 28 & 31 & 24 & 34 & 31 & 40 \\
\hline Tussilago farfara $\mathrm{L}$. & 2 & 10 & 3 & 23 & 20 & 8 & 19 & 11 & 0 & 7 & 6 & 0 & 23 & 12 & 6 & 12 & 10 \\
\hline Veronica serpyllifolia $\mathrm{L}$. & 0 & 0 & 0 & 13 & 13 & 17 & 5 & 6 & 0 & 10 & 0 & 0 & 73 & 15 & 0 & 12 & 8 \\
\hline Vicia cracca $\mathrm{L}$. & 16 & 16 & 3 & 15 & 0 & 13 & 14 & 8 & 7 & 10 & 16 & 14 & 23 & 18 & 9 & 4 & 12 \\
\hline Viola arvensis MURRAY ${ }^{b}$ & 81 & 91 & 93 & 87 & 94 & 92 & 100 & 89 & 83 & 65 & 80 & 56 & 85 & 82 & 71 & 96 & 84 \\
\hline
\end{tabular}

${ }^{\mathrm{a}}=$ incl. G. aparine, $\quad{ }^{\mathrm{b}}=$ incl. V. tricolor 
Vol. 10 (2001): 347-364.

larity coefficient $S_{j}$ (Jaccard 1912) $\left(S_{j}=\mathrm{c} /(\mathrm{A}+\right.$ $\mathrm{B}-\mathrm{c})$, where $\mathrm{c}=$ number of species common to both samples $\mathrm{A}$ and $\mathrm{B}, \mathrm{A}=$ number of species in sample A, B = number of species in sample B). The data were pooled over all fields of each region before the analysis. The results of similarities were presented as dendrograms in which average-linkage clustering (the unweighted pairgroup method) was applied (see Krebs 1999).

The diversity of weed species was described by species richness and evenness. The number of species was used as a measure of species richness. Since the number of species depends on the sample size and since the number of sampled fields varied between regions, total species numbers between regions could not be compared. Therefore, the expected number of species $E\left(S_{n}\right)$ was calculated for each region by rarefaction:

$$
E\left(S_{n}\right)=\sum_{i=1}^{S}\left(1-\frac{\left(\begin{array}{c}
N-N_{i} \\
n
\end{array}\right)}{\left(\begin{array}{l}
N \\
n
\end{array}\right)}\right),
$$

where $E\left(S_{n}\right)=$ expected number of species in a random sample of $n$ individuals, $S=$ total number of species in the entire collection, $N_{i}=$ number of individuals in species $i, N=$ total number of individuals in the collection, $\mathrm{n}=$ sample size (number of individuals) chosen for standardization (see Heck et al. 1975, Krebs 1995).

In rarefaction, the number of species of larger samples are scaled down to the given number of individuals which permits the comparison of species numbers between samples differing in size. Since the lowest number of individuals observed was 3386, we scaled sample sizes down to 3300 individuals in the data sets of all fields. In conventional sprayed and organic fields the lowest numbers of individuals were 1519 and 1867 , respectively, and we scaled the number of individuals down to 1500 . In all data sets, the lowest number of individuals was in the Nurmijärvi region. The sample size of 1500 individuals was used in both data sets to permit the comparison of numbers of species between conventional sprayed and organic fields. Hill's evenness index $\mathrm{E}_{2,1}$

$$
=\frac{\mathrm{N}_{2}}{\mathrm{~N}_{1}}=\frac{\left(\sum_{i} \mathrm{p}_{i}\right)^{-1}}{\exp \left[-\sum_{i} \mathrm{p}_{i} \ln \left(\mathrm{p}_{i}\right)\right]},
$$

where $\mathrm{p}_{i}$ is the proportion of the total sample belonging to the $i$ th species (for properties of the index, see Alatalo 1981) was used as a measure of evenness. Species richness and evenness were calculated for each field separately. Data from the ten $0.1 \mathrm{~m}^{2}$ sample quadrats were pooled before the calculation. The evenness index was calculated by using data on the number of individuals.

\section{Results}

\section{Frequency of weed species}

The occurrence of the 42 most frequent weed species that exceeded the overall frequency level of 5\% in the small sample quadrats is presented by region (Tables 3, 8-9); the remaining species observed from the larger quadrats are listed by region (Appendix 1).

The five most common weed species were Viola arvensis, Stellaria media, Galeopsis spp., Chenopodium album and Elymus repens. These species occurred in more than $60 \%$ of the fields studied (Table 3). In contrast, most of the observed 160 weed species were fairly rare as they were found in less than $2 \%$ of the survey fields (Table 4 and Table 5).

With a frequency of $66 \%$, Elymus repens was by far the most common grass weed (Table 3 ). The next most common grass species, although much lower in the ranking list, were Poa annua (frequency $12 \%$ ), Phleum pratense (3\%) and Alopecurus geniculatus (3\%). With the exception of E. repens and P. апnua, however, the grass species could not always be identified by species at seedling stage. Thus, they were only recorded and pooled to a monocot class that reached a frequency level of $26 \%$.

The ranking list of the ten most frequent weed species in the conventional fields sprayed with 
Salonen, J. et al. Weeds in spring cereals in Finland

Table 4. Distribution of annual and perennial weed species into frequency classes.

\begin{tabular}{|c|c|c|c|c|c|c|}
\hline \multirow{2}{*}{$\begin{array}{l}\text { Frequency } \\
\%\end{array}$} & \multicolumn{4}{|c|}{ Life history } & \multirow[b]{2}{*}{ Total } & \multirow[b]{2}{*}{$\%$} \\
\hline & Annuals & $\%$ & Perennials & $\%$ & & \\
\hline $0-2$ & 34 & 50 & 64 & 70 & 98 & 61 \\
\hline $3-4$ & 4 & 6 & 6 & 7 & 10 & 6 \\
\hline $5-8$ & 1 & 1 & 10 & 11 & 11 & 7 \\
\hline $9-16$ & 9 & 13 & 4 & 4 & 13 & 8 \\
\hline $17-32$ & 4 & 6 & 6 & 7 & 10 & 6 \\
\hline $33-64$ & 13 & 19 & 1 & 1 & 14 & 9 \\
\hline $65-$ & 3 & 4 & 1 & 1 & 4 & 3 \\
\hline Total & 68 & & 92 & & 160 & \\
\hline
\end{tabular}

Table 5. Distribution of broad-leaved and grass weed species into frequency classes.

\begin{tabular}{|c|c|c|c|c|c|c|}
\hline \multirow{2}{*}{$\begin{array}{l}\text { Frequency } \\
\%\end{array}$} & \multicolumn{4}{|c|}{ Growth form } & \multirow[b]{2}{*}{ Total } & \multirow[b]{2}{*}{$\%$} \\
\hline & Broad-leaved & $\%$ & Grass & $\%$ & & \\
\hline $0-2$ & 78 & 58 & 20 & 77 & 98 & 61 \\
\hline $3-4$ & 7 & 5 & 3 & 12 & 10 & 6 \\
\hline $5-8$ & 11 & 8 & 0 & 0 & 11 & 7 \\
\hline $9-16$ & 12 & 9 & 1 & 4 & 13 & 8 \\
\hline $17-32$ & 9 & 7 & 1 & 4 & 10 & 6 \\
\hline $33-64$ & 14 & 10 & 0 & 0 & 14 & 9 \\
\hline $65-$ & 3 & 2 & 1 & 4 & 4 & 3 \\
\hline Total & 134 & & 26 & & 160 & \\
\hline
\end{tabular}

herbicides was somewhat different from that in the organic fields (Table 6). Highly productive perennial weeds occurred more frequently in organic than in conventional farming; Elymus repens had a frequency of $81 \%$ in organic and $60 \%$ in conventional farming, Sonchus arvensis $54 \%$ and $31 \%$ and Cirsium arvense $34 \%$ and $15 \%$, respectively. Similarly, typical grassland weed species such as Achillea millefolium 15\% vs. $2 \%$, Ranunculus repens $30 \%$ vs. $12 \%$ and Taraxacum officinale $30 \%$ vs. $20 \%$ were more frequent in organic than in conventional farming.

The most common weed species were found every year and in all regions, although their rank order varied between the regions. In contrast, some species, e.g. Lamium spp. in south-western Finland, Gnaphalium uliginosum in central
Finland and Veronica serpyllifolia in the Vieremä region, were common only in some regions.

The analysis of species composition with similarity indices revealed two main groups of which the first consisted of two subgroups (Fig. 2), one in south-western (Jokioinen, Laitila and Paimio/Tarvasjoki) and one in southern Finland (Lammi, Iitti, Imatra/Ruokolahti and Nurmijärvi) and the Laihia region in Ostrobothnia. The second main group included regions (Tammela, Mikkeli, Laukaa/Toivakka, Vieremä, Kihniö/ Parkano, Kitee and Nivala) throughout Finland. The most striking difference in species composition between the two main groups was the absence of many species (Cerastium fontanum, Juncus bufonius, Veronica serpyllifolia, Ranunculus acris and Epilobium angustifolium) from some regions of the first group whereas in the 
Vol. 10 (2001): 347-364.

Table 6. Frequency of ten most common weed species in two cropping systems.

\begin{tabular}{cllll}
\hline Rank & Sprayed conventional $(\mathrm{N}=457)$ & $\%$ & Organic $(\mathrm{N}=165)$ & $\%$ \\
\hline 1 & Viola arvensis & 81 & Chenopodium album & 96 \\
2 & Stellaria media & 65 & Stellaria media & 95 \\
3 & Elymus repens & 60 & Galeopsis spp. & 93 \\
4 & Galeopsis spp. & 60 & Viola arvensis & 93 \\
5 & Chenopodium album & 53 & Spergula arvensis & 83 \\
6 & Lapsana communis & 52 & Erysimum cheiranthoides & 82 \\
7 & Polygonum aviculare & 50 & Elymus repens & 81 \\
8 & Fallopia convolvulus & 48 & Polygonum aviculare & 70 \\
9 & Galium spurium & 43 & Fallopia convolvulus & 63 \\
10 & Fumaria officinalis & 39 & Myosotis arvensis & 60 \\
\hline
\end{tabular}

second group they were found in all regions (Table 3). The species composition in the Nauvo/ Korppoo region (no organic farming) differed most markedly from that in any of the other regions because some species, e.g. Gnaphalium uliginosum, Persicaria hydropiper and Poa annua, were not found there at all (Table 3).

\section{Species diversity}

Altogether 188 weed species were found in the large $\left(1.0 \mathrm{~m}^{2}\right)$ sampling quadrats and 160 in the small $\left(0.1 \mathrm{~m}^{2}\right)$ quadrats. The total number of observed species, $\mathrm{S}_{\mathrm{OBS}}$, in regions ranged from 41 to 84 (Table 7). In three regions (Nauvo/Korppoo, Laihia and Nurmijärvi), the number of observed species was below 50 and in two regions (Tammela and Mikkeli) it exceeded 80. The same regions had the lowest and the highest expected number of species, $E\left(\mathrm{~S}_{\mathrm{n}}\right)$, calculated by rarefaction analysis (Table 7). No clear regional trend in the variation in the total number of species was observed. For example, the regions with the highest species number included regions in both eastern (Kitee, Mikkeli and Imatra/Ruokolahti) and south-western (Tammela and Paimio/Tarvasjoki) Finland.

In 11 out of 15 regions, the total number of observed species, $\mathrm{S}_{\mathrm{OBS}}$, was higher in organically farmed than in sprayed conventional fields, whereas the expected number of species, $E\left(\mathrm{~S}_{\mathrm{n}}\right)$,

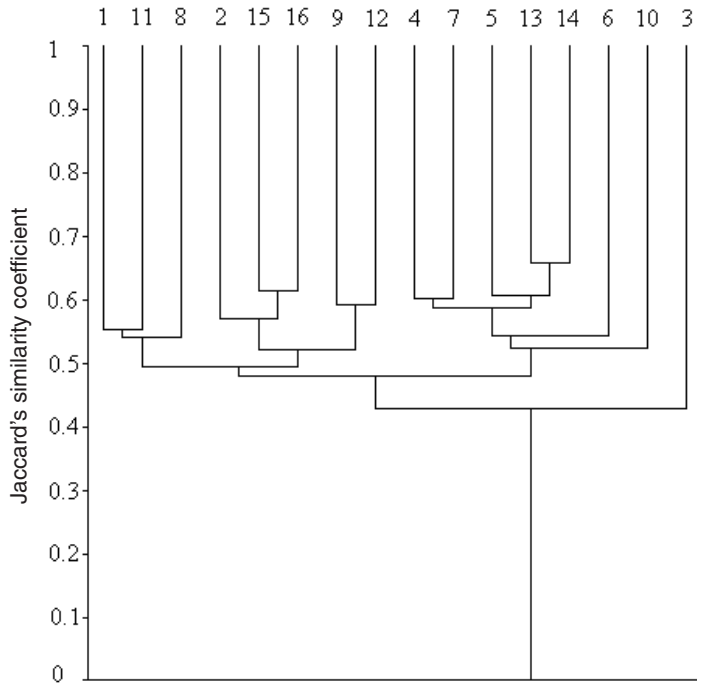

Fig. 2. Similarity (Jaccard's similarity coefficient) of weed communities between regions. Key to region numbers: $1=$ Jokioinen, 2 = Lammi, 3 = Nauvo/Korppoo, 4 = Tammela, 5 = Laukaa/Toivakka, $6=$ Kitee, $7=$ Mikkeli, $8=$ Paimio/ Tarvasjoki, $9=$ Laihia, $10=$ Nivala, $11=$ Laitila, $12=$ Nurmijärvi, 13 = Vieremä, 14 = Kihniö/Parkano, 15 = Iitti, $16=$ Imatra/Ruokolahti.

was higher in organically farmed fields in nine regions (Table 7). However, even though the number of species might be almost the same, the species composition could be very different. For example, in the Imatra/Ruokolahti region the difference in the number of observed species, $\mathrm{S}_{\mathrm{OBS}}$, was only two but the proportion of co-occurring species was as low as $54.9 \%$ (Table 7). 
Salonen, J. et al. Weeds in spring cereals in Finland

Table 7. Observed $\left(\mathrm{S}_{\mathrm{OBS}}\right)$ and rarefied $\left(E\left(\mathrm{~S}_{\mathrm{n}}\right)\right.$ with $\left.S D\right)$ number of species by region and production type, and proportion of co-occurring species between sprayed conventional and organic fields.

\begin{tabular}{|c|c|c|c|c|c|c|c|c|c|c|}
\hline \multirow[t]{2}{*}{ Region } & \multicolumn{3}{|c|}{ All fields } & \multicolumn{3}{|c|}{ Conventional sprayed } & \multicolumn{3}{|c|}{ Organic } & \multirow{2}{*}{$\begin{array}{l}\text { Co-occurring } \\
\text { species (\%) }\end{array}$} \\
\hline & $\mathrm{S}_{\mathrm{OBS}}$ & $E\left(\mathrm{~S}_{3300}\right)$ & $S D$ & $\mathrm{~S}_{\mathrm{OBS}}$ & $E\left(\mathrm{~S}_{1500}\right)$ & $S D$ & $\mathrm{~S}_{\mathrm{OBS}}$ & $E\left(\mathrm{~S}_{1500}\right)$ & $S D$ & \\
\hline 1 Jokioinen & 54 & 51.8 & 1.24 & 41 & 38.0 & 1.27 & 47 & 41.5 & 1.63 & 66.7 \\
\hline 2 Lammi & 62 & 53.2 & 2.04 & 48 & 39.8 & 2.01 & 57 & 44.7 & 2.19 & 72.6 \\
\hline 3 Nauvo/Korppoo & 41 & 38.1 & 1.41 & 39 & 34.0 & 1.62 & - & - & - & - \\
\hline 4 Tammela & 84 & 64.6 & 2.64 & 65 & 51.3 & 2.35 & 55 & 48.2 & 2.00 & 57.1 \\
\hline 5 Laukaa/Toivakka & 68 & 57.1 & 2.13 & 48 & 40.2 & 1.76 & 53 & 46.1 & 2.03 & 64.7 \\
\hline 6 Kitee & 72 & 62.5 & 2.11 & 47 & 43.3 & 1.54 & 60 & 52.2 & 1.92 & 59.7 \\
\hline 7 Mikkeli & 81 & 69.5 & 2.41 & 66 & 56.7 & 2.24 & 64 & 50.1 & 2.47 & 60.5 \\
\hline 8 Paimio/Tarvasjoki & 72 & 56.9 & 2.40 & 46 & 40.5 & 1.77 & 55 & 42.0 & 2.30 & 54.2 \\
\hline 9 Laihia & 42 & 41.2 & 0.81 & 40 & 38.0 & 1.23 & 26 & 25.2 & 0.81 & 57.1 \\
\hline 10 Nivala & 56 & 44.8 & 2.21 & 42 & 37.1 & 1.71 & 47 & 33.8 & 2.12 & 64.3 \\
\hline 11 Laitila & 61 & 48.4 & 2.38 & 51 & 40.5 & 2.26 & 46 & 36.9 & 1.83 & 59.0 \\
\hline 12 Nurmijärvi & 44 & 43.9 & 0.36 & 33 & 32.9 & 0.27 & 40 & 38.7 & 1.03 & 65.9 \\
\hline 13 Vieremä & 66 & 55.4 & 2.36 & 47 & 45.3 & 1.20 & 49 & 40.4 & 1.90 & 68.2 \\
\hline 14 Kihniö/Parkano & 60 & 54.5 & 1.59 & 39 & 34.5 & 1.62 & 47 & 43.2 & 1.46 & 63.3 \\
\hline 15 Iitti & 55 & 51.0 & 1.63 & 43 & 35.0 & 1.99 & 46 & 36.5 & 1.98 & 67.3 \\
\hline 16 Imatra/Ruokolahti & 71 & 61.9 & 2.17 & 54 & 43.9 & 2.12 & 56 & 49.7 & 1.85 & 54.9 \\
\hline
\end{tabular}

The average number of weed species per field was 18 . In organically farmed fields, the average species number was 24 and in conventionally farmed fields 16 . However, in conventional fields the difference between sprayed and unsprayed fields was ten species (15 vs. 25 species). The difference in the average number of weed species between the poorest and the richest regions was 11 in both sprayed conventional and organic fields (Fig. 3). The number of species was, however, higher in organic fields (variation in averages 14-25.1) than in sprayed conventional fields (6.6-17.6). The greater the number of species in sprayed conventional fields, the lower were the values of the evenness index (i.e. some species dominated the weed community); a similar trend was not observed in organic fields.

\section{Weed density}

The average density of weeds in all fields studied was 243 plants $\mathrm{m}^{-2}(\mathrm{SD}=261$, median $=160, \mathrm{~N}$ $=690$ ). Correspondingly, the average density of weeds in sprayed conventional fields was 136 plants $\mathrm{m}^{-2}(\mathrm{SD}=136$, median $=91, \mathrm{~N}=457)$ and in organic production 469 plants $\mathrm{m}^{-2}(\mathrm{SD}=$ 340 , median $=395, \mathrm{~N}=165$ ). The average weed density in untreated conventional fields was 420 plants $\mathrm{m}^{-2}(\mathrm{SD}=238$, median $=374, \mathrm{~N}=68)$.

The three most abundant weed species accounted for $32-53 \%$ of the total density in each region. There were considerable differences in the abundance of weeds between the regions (Table 8), reflecting both annually changing factors such as weed control measures and weather conditions and more permanent factors such as soil conditions and farming practices. Some less frequent species, e.g. Juncus bufonius, Persicaria hydropiper and Veronica serpyllifolia, were of importance in some regions.

The five most abundant weed species in organic fields were Chenopodium album (on average 91 plants $\mathrm{m}^{-2}$ ), Elymus repens (49), Spergula arvensis (49), Stellaria media (49) and Viola arvensis (31). Correspondingly, the five most abundant weed species in sprayed conventional fields were Elymus repens (21 plants $\mathrm{m}^{-2}$ ), Viola arvensis (15), Stellaria media (12), Chenopodium album (8), and Spergula arvensis (7). 
Vol. 10 (2001): 347-364.
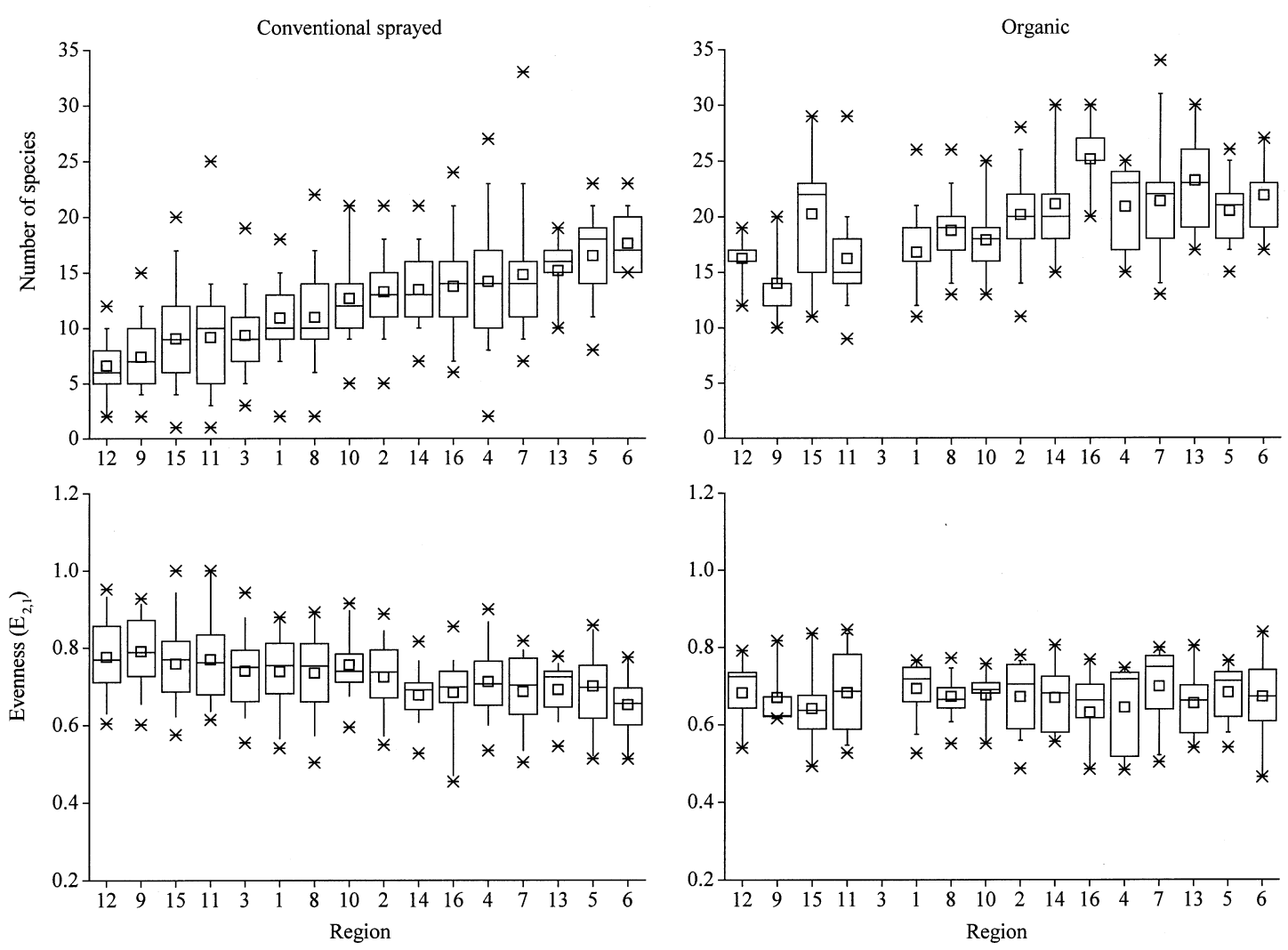

Fig. 3. Number of species and values of evenness index $\left(\mathrm{E}_{2,1}\right)$ by region in sprayed conventional and organically cultivated fields. The square in the box denotes the mean of the data, and the horizontal lines the 25 th, 50 th and 75 th percentile values. The error bars denote the 5th and 95th percentile values, and the crosses below and above them the 1st and the 99th percentile values, respectively. Key to region numbers: $1=$ Jokioinen, $2=$ Lammi, $3=$ Nauvo/Korppoo, $4=$ Tammela, $5=$ Laukaa/Toivakka, $6=$ Kitee, $7=$ Mikkeli, $8=$ Paimio/Tarvasjoki, $9=$ Laihia, $10=$ Nivala, $11=$ Laitila, $12=$ Nurmijärvi, 13 = Vieremä, 14 = Kihniö/Parkano, 15 = Iitti, 16 = Imatra/Ruokolahti.

\section{Weed biomass}

The average biomass production of weeds was $329 \mathrm{~kg} \mathrm{ha}^{-1}(\mathrm{SD}=444$, median $=141, \mathrm{~N}=690)$ (Table 9). The difference between cropping practices was considerable, as in sprayed conventional fields the average weed biomass was $163 \mathrm{~kg}$ $\mathrm{ha}^{-1}(\mathrm{SD}=248$, median $=63, \mathrm{~N}=457)$ and in organic production it was about four times as high, namely $678 \mathrm{~kg} \mathrm{ha}^{-1}(\mathrm{SD}=547$, median $=$ $567, \mathrm{~N}=165$ ). Moreover, in terms of median values, the difference in biomass production was 9 -fold. In untreated conventional fields the aver- age weed biomass was $605 \mathrm{~kg} \mathrm{ha}^{-1}(\mathrm{SD}=560$, median $=413, \mathrm{~N}=68$ ).

Although the average biomass production of weeds varied between the regions (Table 9), the annual averages pooled over the regions were at roughly the same level: $227 \mathrm{~kg} \mathrm{ha}^{-1}$ in 1997 , $251 \mathrm{~kg} \mathrm{ha}^{-1}$ in 1998 and $244 \mathrm{~kg} \mathrm{ha}^{-1}$ in 1999.

In all regions, the three most abundant weed species together accounted for more than 50\% of the average total biomass production in the region. The same species were quite often the most productive (e.g. Elymus repens, Chenopodium album) in different regions. Perennial 


\section{Salonen, J. et al. Weeds in spring cereals in Finland}

Table 8 . Weed density (plants $\mathrm{m}^{-2}$ ) by region. + indicates $<1$ plant $\mathrm{m}^{-2}$.

\begin{tabular}{|c|c|c|c|c|c|c|c|c|c|c|c|c|c|c|c|c|c|}
\hline \multirow{3}{*}{ Species / Taxon } & \multicolumn{16}{|c|}{ Year / Region } & \multirow{3}{*}{$\begin{array}{l}\text { Average } \\
1997-99\end{array}$} \\
\hline & \multicolumn{2}{|c|}{1997} & \multicolumn{6}{|c|}{1998} & \multicolumn{8}{|c|}{1999} & \\
\hline & 1 & 2 & 3 & 4 & 5 & 6 & 7 & 8 & 9 & 10 & 11 & 12 & 13 & 14 & 15 & 16 & \\
\hline Achillea millefolium & + & + & 0 & + & + & + & + & 0 & 0 & + & + & + & + & + & + & + & + \\
\hline Brassica rapa ssp. oleifera & + & + & 0 & + & + & 0 & + & + & 2 & 0 & 1 & + & 0 & + & + & + & + \\
\hline Capsella bursa-pastoris & + & 2 & 1 & 3 & 2 & 8 & 6 & + & + & + & 1 & + & + & 2 & 2 & + & 2 \\
\hline Cerastium fontanum & 0 & + & 0 & + & + & 5 & + & + & + & + & 0 & 0 & 1 & 2 & 0 & + & + \\
\hline Chenopodium album & 22 & 63 & 17 & 21 & 13 & 28 & 24 & 18 & 23 & 73 & 48 & 24 & 32 & 39 & 83 & 16 & 33 \\
\hline Cirsium arvense & 1 & + & + & + & + & + & + & 1 & + & + & + & 1 & + & + & 1 & + & + \\
\hline Elymus repens & 28 & 23 & 11 & 33 & 32 & 73 & 49 & 9 & 6 & 45 & 18 & 11 & 22 & 37 & 58 & 81 & 29 \\
\hline Epilobium angustifolium & + & 0 & 0 & + & + & + & + & + & 0 & + & + & 0 & + & 1 & 0 & + & + \\
\hline Equisetum arvense & 1 & + & 1 & 1 & + & + & + & 3 & + & + & + & + & + & 1 & + & + & + \\
\hline Erysimum cheiranthoides & 3 & 5 & 3 & 3 & 8 & 7 & 10 & 5 & 9 & 10 & 2 & + & 3 & 10 & 12 & 3 & 6 \\
\hline Fallopia convolvulus & 3 & 4 & 1 & 7 & + & 1 & 1 & 5 & 6 & 2 & 4 & 6 & + & + & 9 & 21 & 4 \\
\hline Fumaria officinalis & 2 & 3 & 2 & 2 & 7 & 2 & + & 2 & + & + & 1 & 6 & + & 2 & 3 & 3 & 2 \\
\hline Galeopsis spp. & 9 & 19 & + & 9 & 17 & 6 & 9 & 8 & 7 & 42 & 12 & 3 & 24 & 14 & 7 & 3 & 12 \\
\hline Galium spurium & 4 & 9 & 14 & 5 & + & + & + & 4 & 3 & + & 5 & 2 & + & 0 & 7 & 10 & 4 \\
\hline Gnaphalium uliginosum & + & 6 & 0 & 11 & 31 & 28 & 11 & 1 & 0 & 29 & + & + & 37 & 12 & 2 & 9 & 9 \\
\hline Juncus bufonius & 0 & + & 0 & 4 & 3 & 1 & 8 & 0 & 0 & 2 & 0 & 0 & + & 1 & 0 & + & 1 \\
\hline Lamium spp. & 5 & 2 & 10 & 2 & 4 & + & + & 10 & + & 0 & 2 & 2 & 0 & + & 2 & 8 & 3 \\
\hline Lapsana communis & 3 & 13 & 5 & 9 & 13 & 18 & 17 & 1 & + & 0 & 14 & 1 & 0 & + & 14 & 35 & 8 \\
\hline Lathyrus pratensis & + & + & 0 & + & 0 & 0 & + & + & + & + & 0 & + & + & 0 & + & + & + \\
\hline Matricaria matricarioides & 5 & 2 & 2 & 3 & 31 & 16 & 10 & 4 & + & 25 & 1 & 0 & 18 & 23 & 6 & 10 & 8 \\
\hline Myosotis arvensis & 1 & 3 & + & 9 & 7 & 4 & 12 & 8 & 1 & 3 & 3 & + & 2 & 3 & 3 & 5 & 4 \\
\hline Persicaria hydropiper & 0 & 0 & 0 & 2 & 3 & 1 & 2 & 0 & 0 & + & 3 & 0 & 0 & + & + & 2 & + \\
\hline Persicaria lapathifolia & 11 & 13 & 4 & 4 & 9 & 3 & 3 & 2 & 1 & 27 & 3 & + & 18 & 9 & + & 2 & 7 \\
\hline Persicaria maculosa & 0 & 0 & 0 & + & 0 & 0 & 0 & 5 & 0 & 0 & + & + & 0 & 0 & + & + & + \\
\hline Plantago major & + & + & + & 1 & 8 & 13 & 5 & + & + & 3 & + & 0 & 15 & + & 1 & 3 & 2 \\
\hline Роа аппиа & + & + & 0 & 5 & 2 & 9 & 16 & + & + & + & 3 & + & 2 & + & + & 8 & 3 \\
\hline Polygonum aviculare & 2 & 2 & 1 & 4 & 2 & 5 & + & 2 & 1 & 5 & 9 & 7 & 12 & 6 & 6 & 4 & 4 \\
\hline Ranunculus acris & + & + & 0 & + & 2 & + & + & + & 0 & + & + & 0 & 1 & 13 & 0 & 0 & + \\
\hline Ranunculus repens & 0 & 1 & + & + & 3 & 6 & 1 & + & + & 12 & + & + & 8 & 3 & + & + & 2 \\
\hline Rumex acetosa & 0 & + & 0 & 0 & 1 & 0 & + & + & 0 & + & + & 0 & + & 2 & 0 & + & + \\
\hline Rumex acetosella & 1 & + & 0 & + & + & + & + & + & + & + & 0 & 0 & + & 0 & 0 & + & + \\
\hline Sonchus arvensis & 1 & 7 & 1 & 6 & 14 & 1 & 7 & 1 & + & 3 & 4 & + & 3 & 2 & 4 & 8 & 4 \\
\hline Spergula arvensis & 19 & 20 & 8 & 19 & 52 & 28 & 25 & 5 & 1 & 46 & 9 & 2 & 36 & 41 & 18 & 10 & 20 \\
\hline Stellaria media & 24 & 28 & 10 & 48 & 32 & 22 & 17 & 32 & 8 & 62 & 25 & 3 & 17 & 19 & 14 & 25 & 25 \\
\hline Taraxacum officinale & 2 & + & + & 1 & + & 6 & + & 4 & 0 & + & 0 & + & 3 & 1 & + & 3 & 1 \\
\hline Thlaspi arvense & + & 1 & + & + & + & + & + & + & + & 1 & + & + & 0 & 1 & 10 & 2 & 1 \\
\hline Trifolium spp. & + & 6 & + & 2 & 3 & 5 & 3 & + & + & 2 & 2 & + & 6 & 4 & 10 & + & 3 \\
\hline Tripleurospermum inodorum & 3 & 5 & 1 & 2 & 6 & 3 & 2 & 16 & + & 5 & 2 & + & 3 & 2 & 4 & + & 4 \\
\hline Tussilago farfara & + & + & + & 2 & 2 & 1 & 3 & + & 0 & + & + & 0 & + & + & + & 1 & + \\
\hline Veronica serpyllifolia & 0 & 0 & 0 & + & 2 & + & + & + & 0 & + & 0 & 0 & 6 & 3 & 0 & + & + \\
\hline Vicia cracca & + & + & + & 1 & 0 & + & + & + & + & + & + & + & + & + & + & + & + \\
\hline Viola arvensis & 12 & 29 & 30 & 14 & 16 & 20 & 30 & 19 & 15 & 25 & 23 & 6 & 12 & 13 & 17 & 28 & 19 \\
\hline Other broad-leaved & 4 & 5 & 2 & 6 & 9 & 18 & 6 & 13 & + & 7 & 3 & 1 & 10 & 14 & 11 & 8 & 7 \\
\hline Other grasses & + & 6 & 1 & 3 & 28 & 7 & 16 & 10 & 6 & 28 & 3 & + & 39 & 41 & 6 & 3 & 11 \\
\hline Mean total, plants $\mathrm{m}^{-2}$ & 173 & 280 & 129 & 245 & 365 & 350 & 302 & 187 & 96 & 459 & 202 & 79 & 330 & 322 & 303 & 314 & 243 \\
\hline Median total, plants $\mathrm{m}^{-2}$ & 108 & 208 & 88 & 188 & 290 & 270 & 249 & 129 & 52 & 299 & 105 & 41 & 298 & 255 & 134 & 305 & 160 \\
\hline
\end{tabular}


Vol. 10 (2001): 347-364.

weeds such as Cirsium arvense, Sonchus arvensis and Tussilago farfara also ranked high, since one individual perennial plant alone may produce more biomass than 100 seedlings of annual broad-leaved weeds.

The five weed species producing the highest amounts of biomass in organic fields were Elymus repens (average $178 \mathrm{~kg} / \mathrm{ha}$ ), Chenopodium album (140), Spergula arvensis (53), Galeopsis spp. (47) and Stellaria media (37). Correspondingly, the five most productive weed species in sprayed conventional fields were Elymus repens (81 kg ha $\left.{ }^{-1}\right)$, Chenopodium album (10), Stellaria media (7), Galeopsis spp. (7), and Persicaria lapathifolia (6).

The average biomasses of individual weed plants and their rank order differed in sprayed conventional and organic cropping as indicated in the list of the 15 most productive species (Table 10). Eleven of these were the same species in both cropping types.

Broad-leaved species accounted for $43 \%$ of the average total biomass production in sprayed conventional fields and for $72 \%$ in organic fields. Elymus repens was the most efficient biomass producer, as it accounted for $26 \%$ of the total weed biomass production pooled over all organic fields and for as much as $50 \%$ in sprayed conventional fields.

In all, the proportion of weed biomass relative to total vegetative biomass (crop + weeds) was fairly low (mean $=3.0 \%$ ) in sprayed conventional fields, somewhat higher $($ mean $=$ $12.6 \%$ ) in untreated conventional fields and highest $($ mean $=17.1 \%)$ in organic fields.

\section{Discussion}

Species diversity in cereal fields was fairly high, a total of 160 weed species, actually 188 species, being found in the surveyed fields. The classification of species into broad-leaved/grass and annual/perennial types showed a similar distribution over the frequency classes. Characteris- tic of weed infestation in spring cereal fields is the occurrence of broad-leaved annuals and Elymus repens.

Only 42 weed species/taxa exceeded the overall frequency level of 5\%. Furthermore, although the number of weed species observed was fairly high, the number of dominant weed species was quite low, as only 18 species exceeded the frequency level of $33 \%$ and more than $60 \%$ of the species remained below the $2 \%$ frequency level. In terms of successful cereal production, shifts in the rank order of the most frequent and dominant species should have greater implications for the planning of weed management than have actual changes in the diversity of weed communities, as suggested also by Légère and Derksen (2000).

The present finding of 160 (188) weed species along with the earlier finding of 304 species (Mukula et al. 1969) shows that spring cereal fields support a much more diverse weed flora than which is important in terms of crop protection. Due to the difference in sample sizes, however, the findings of these two surveys cannot be directly compared. Further, we may expect that some weed species detected previously are now extinct or extremely rare in Finnish arable fields. Such a decline in arable flora has been observed in other countries, too (Albrecht 1995, Andreasen et al. 1996, Sutcliffe and Kay 2000).

Regional specialization of agricultural practices has taken place in many countries - including Finland - during the last decades. The study regions in southern and south-western Finland can be regarded as this country's main cereal production area. In other study regions, the use of arable land is more diverse as many farms base their crop rotation on grassland for silage and hay and pasture for cattle. These two areas proved to have a different weed species composition and species diversity. Regions in central and eastern Finland had, in general, higher average weed species numbers than did regions in southern and south-western Finland. Species absent from southern and south-western Finland were those typical of Finnish grasslands (Raa- 
Salonen, J. et al. Weeds in spring cereals in Finland

Table 9. Average biomass $\left(\mathrm{kg} \mathrm{ha}^{-1}\right)$ of weeds by region. + indicates $<1 \mathrm{~kg} \mathrm{ha}^{-1}$.

\begin{tabular}{|c|c|c|c|c|c|c|c|c|c|c|c|c|c|c|c|c|c|}
\hline \multirow{3}{*}{ Species / Taxon } & \multicolumn{16}{|c|}{ Year / Region } & \multirow{3}{*}{$\begin{array}{l}\text { Average } \\
1997-99\end{array}$} \\
\hline & \multicolumn{2}{|c|}{1997} & \multicolumn{6}{|c|}{1998} & \multicolumn{8}{|c|}{1999} & \\
\hline & 1 & 2 & 3 & 4 & 5 & 6 & 7 & 8 & 9 & 10 & 11 & 12 & 13 & 14 & 15 & 16 & \\
\hline Achillea millefolium & 0 & 2 & 0 & + & + & 2 & + & 0 & 0 & 0 & 0 & + & + & 2 & + & 0 & + \\
\hline Brassica rapa ssp. oleifera & 4 & 2 & 0 & + & + & 0 & 0 & + & 2 & 0 & 17 & 1 & 0 & 3 & + & 0 & 2 \\
\hline Capsella bursa-pastoris & + & + & + & + & 1 & 3 & 5 & + & 0 & 0 & + & 0 & + & 3 & + & + & + \\
\hline Cerastium fontanum & 0 & 0 & 0 & 0 & 0 & + & + & 0 & 0 & 0 & 0 & 0 & + & 1 & 0 & 0 & + \\
\hline Chenopodium album & 31 & 123 & 4 & 10 & 7 & 17 & 11 & 4 & 95 & 75 & 93 & 31 & 107 & 60 & 69 & 53 & 47 \\
\hline Cirsium arvense & 11 & 3 & 9 & 31 & 0 & 0 & + & 32 & 2 & + & 0 & 9 & 7 & + & 7 & 8 & 9 \\
\hline Elymus repens & 102 & 91 & 49 & 140 & 154 & 175 & 215 & 58 & 41 & 142 & 63 & 43 & 136 & 128 & 133 & 309 & 112 \\
\hline Epilobium angustifolium & 0 & 0 & 0 & 0 & + & + & + & 0 & 0 & 0 & 0 & 0 & + & 3 & 0 & + & + \\
\hline Equisetum arvense & 2 & + & 6 & 6 & + & 0 & 2 & 11 & 3 & + & 2 & 5 & 4 & 2 & 0 & 0 & 3 \\
\hline Erysimum cheiranthoides & + & 3 & + & 2 & 2 & 4 & 8 & 2 & 14 & 4 & 1 & + & 3 & 15 & 14 & 6 & 4 \\
\hline Fallopia convolvulus & 6 & 9 & + & 8 & + & + & 1 & 4 & 9 & 3 & 8 & 13 & 0 & + & 15 & 32 & 7 \\
\hline Fumaria officinalis & 2 & 2 & + & 2 & 7 & 2 & + & 2 & 3 & + & 5 & 2 & + & 3 & 4 & 3 & 2 \\
\hline Galeopsis spp. & 11 & 25 & + & 25 & 28 & 15 & 27 & 25 & 31 & 46 & 27 & 3 & 50 & 31 & 10 & 8 & 22 \\
\hline Galium spurium & 2 & 8 & 9 & 7 & + & + & 3 & 11 & 1 & 0 & 7 & + & 0 & 0 & 3 & 4 & 4 \\
\hline Gnaphalium uliginosum & 0 & + & 0 & 2 & 3 & + & + & 0 & 0 & 3 & 0 & 0 & 3 & 1 & 0 & + & + \\
\hline Juncus bufonius & 0 & + & 0 & 4 & + & + & 6 & 0 & 0 & 0 & 0 & 0 & + & + & 0 & 0 & + \\
\hline Lamium spp. & 2 & + & 1 & 1 & 2 & + & 0 & 6 & 0 & 0 & 1 & 1 & 0 & + & + & 3 & 1 \\
\hline Lapsana communis & + & 11 & + & 10 & 6 & 16 & 18 & + & + & 0 & 10 & + & 0 & + & 5 & 33 & 6 \\
\hline Lathyrus pratensis & + & 0 & 0 & 3 & 0 & 0 & 0 & + & 0 & 0 & 0 & 0 & + & 0 & 0 & + & + \\
\hline Matricaria matricarioides & + & + & + & 1 & 16 & 5 & 3 & 2 & 0 & 6 & + & 0 & 15 & 9 & 2 & 4 & 3 \\
\hline Myosotis arvensis & 0 & 1 & + & 3 & 2 & 1 & 6 & 1 & + & + & + & 0 & + & 1 & + & 1 & 1 \\
\hline Persicaria hydropiper & 0 & 0 & 0 & 3 & + & 2 & 3 & 0 & 0 & + & + & 0 & 0 & + & + & 2 & + \\
\hline Persicaria lapathifolia & 9 & 37 & 5 & 8 & 14 & 3 & 5 & 3 & 4 & 77 & 4 & 0 & 28 & 13 & + & 14 & 13 \\
\hline Persicaria maculosa & 0 & 0 & 0 & + & 0 & 0 & 0 & 1 & 0 & 0 & + & + & 0 & 0 & 1 & + & + \\
\hline Plantago major & 1 & 0 & + & + & 3 & 2 & 7 & + & + & + & + & 0 & 2 & + & + & 2 & 1 \\
\hline Роа аппиа & + & + & 0 & 3 & + & 1 & 3 & + & + & 0 & + & + & + & + & 0 & 1 & + \\
\hline Polygonum aviculare & 2 & 3 & 1 & 3 & 2 & 4 & + & + & 2 & 6 & 9 & 10 & 34 & 7 & 4 & 7 & 5 \\
\hline Ranunculus acris & 0 & 0 & 0 & 0 & + & 0 & 0 & 0 & 0 & 0 & 0 & 0 & + & 2 & 0 & 0 & + \\
\hline Ranunculus repens & 0 & + & 0 & + & 3 & 2 & 2 & + & 0 & 4 & 0 & 0 & 4 & 3 & 0 & + & + \\
\hline Rumex acetosa & 0 & 0 & 0 & 0 & + & 0 & 0 & 0 & 0 & + & 0 & 0 & + & 1 & 0 & 0 & + \\
\hline Rumex acetosella & + & 0 & 0 & + & + & + & + & 0 & + & + & 0 & 0 & 0 & 0 & 0 & 0 & + \\
\hline Sonchus arvensis & 5 & 19 & 1 & 31 & 27 & + & 30 & + & + & 9 & 8 & + & 5 & 4 & 9 & 35 & 11 \\
\hline Spergula arvensis & 2 & 14 & 8 & 23 & 44 & 17 & 36 & 5 & 3 & 50 & 26 & + & 56 & 65 & 9 & 7 & 20 \\
\hline Stellaria media & 6 & 9 & 2 & 52 & 28 & 37 & 20 & 35 & 6 & 32 & 14 & 1 & 19 & 16 & 6 & 16 & 19 \\
\hline Taraxacum officinale & 0 & + & 0 & + & + & 9 & + & + & 0 & 0 & 0 & 3 & + & + & + & 0 & + \\
\hline Thlaspi arvense & 0 & + & 0 & + & + & 1 & + & 0 & + & + & + & 0 & 0 & 2 & 5 & 1 & + \\
\hline Trifolium spp. & + & 5 & 0 & + & 2 & + & 2 & + & + & + & + & + & 6 & 1 & 8 & + & 2 \\
\hline Tripleurospermum inodorum & + & 1 & + & 2 & 6 & + & 2 & 3 & + & 2 & 1 & + & 4 & 1 & 1 & 2 & 2 \\
\hline Tussilago farfara & 0 & 1 & 0 & 45 & 3 & + & 5 & + & 0 & + & 1 & 0 & 0 & 2 & 0 & + & 4 \\
\hline Veronica serpyllifolia & 0 & 0 & 0 & 0 & + & 0 & 0 & 0 & 0 & 0 & 0 & 0 & + & + & 0 & 0 & 0 \\
\hline Vicia cracca & + & 5 & 0 & 3 & 0 & 0 & 3 & 0 & + & + & 1 & + & + & 2 & + & 0 & 1 \\
\hline Viola arvensis & 1 & 5 & 3 & 6 & 3 & 4 & 11 & 3 & 3 & 7 & 7 & + & 3 & 7 & 2 & 14 & 5 \\
\hline Other broad-leaved & 2 & 4 & 1 & 6 & 2 & 9 & 4 & 3 & + & 3 & 6 & 2 & + & 4 & 11 & 25 & 5 \\
\hline Other grasses & 0 & 6 & + & 7 & 35 & 5 & 31 & 4 & 5 & 7 & 2 & + & 48 & 16 & 3 & 6 & 10 \\
\hline Mean total, kg ha-1 & 204 & 389 & 103 & 448 & 402 & 342 & 468 & 216 & 225 & 478 & 319 & 129 & 537 & 408 & 317 & 599 & 329 \\
\hline Median total, kg ha-1 & 86 & 233 & 38 & 193 & 288 & 273 & 316 & 63 & 53 & 190 & 98 & 35 & 509 & 200 & 173 & 294 & 141 \\
\hline
\end{tabular}


Vol. 10 (2001): 347-364.

Table 10. The 15 most productive weed species (air-dry biomass, g/plant) in two cropping types.

\begin{tabular}{lcclrc}
\hline \multicolumn{2}{c}{ Sprayed conventional } & & & Organic \\
\hline Species & $\mathrm{g}$ & No of fields & Species & $\mathrm{g}$ & No of fields \\
\hline Galeopsis speciosa & 0.63 & 38 & Cirsium arvense & 2.39 & 56 \\
Equisetum arvense & 0.47 & 62 & Brassica rapa ssp. oleifera & 1.02 & 26 \\
Elymus repens & 0.44 & 273 & Vicia cracca & 0.41 & 41 \\
Brassica rapa ssp. oleifera & 0.25 & 28 & Elymus repens & 0.37 & 133 \\
Tussilago farfara & 0.24 & 24 & Persicaria lapathifolia & 0.35 & 87 \\
Galeopsis bifida & 0.24 & 92 & Galeopsis speciosa & 0.34 & 51 \\
Cirsium arvense & 0.24 & 70 & Equisetum arvense & 0.29 & 45 \\
Persicaria lapathifolia & 0.16 & 153 & Galeopsis bifida & 0.28 & 90 \\
Fallopia convolvulus & 0.15 & 219 & Fallopia convolvulus & 0.24 & 104 \\
Taraxacum officinale & 0.11 & 93 & Sonchus arvensis & 0.20 & 89 \\
Sonchus arvensis & 0.11 & 140 & Lathyrus pratensis & 0.18 & 20 \\
Fumaria officinalis & 0.10 & 180 & Chenopodium album & 0.17 & 159 \\
Polygonum aviculare & 0.10 & 228 & Polygonum aviculare & 0.16 & 115 \\
Chenopodium album & 0.10 & 241 & Achillea millefolium & 0.13 \\
Lapsana communis & 0.09 & 236 & Spergula arvensis & 0.12 & 137 \\
\hline
\end{tabular}

tikainen and Raatikainen 1975). Therefore, regional specialization in agricultural production can be regarded as one reason for differences in the composition of weed communities between these two areas.

Another factor affecting the species composition in different regions (probably in interaction with cropping practices) was soil properties, organic soils being predominant in some regions of central and eastern Finland (e.g. Kitee and Nivala). Soil properties have been found to be an important factor explaining the species composition of weed communities (Andreasen et al. 1991). Salonen (1993) and Erviö et al. (1994) analysed the data of the second weed survey and found that Chenopodium album, Lamium spp. and Fallopia convolvulus were more abundant in clay than in coarse mineral or organic soils. Furthermore, Galeopsis spp. and Polygonum lapathifolium favoured organic soils and Poa annua and Lapsana communis coarse mineral soils.

It should also be kept in mind that in both cereal and animal husbandry production systems the intensity of farming has increased tremendously and in many ways. The most striking changes during the last four decades have been the greater use of herbicides, increased nitrogen fertilization and improved tillage and sowing practices with combined seed and fertilizer drill methods (Elonen 1983, Mukula and Rantanen 1987). It is thus unlikely that any single factor alone can adequately explain the changes in weed flora (Haas and Streibig 1982, Salonen 1993).

Another factor which should be taken into account when comparing regions is that the surveys were conducted in different years and under different weather conditions. Both 1997 and 1999 were fairly dry years, whereas 1998 was very wet. Surprisingly, however, the annual averages of weed biomass pooled over the regions were close to each other. Moreover, some regions were studied during the latter part of the onemonth survey period; this obviously had some effect on the biomass results but not so much on the frequency and density records. Therefore, it was appropriate to use a qualitative similarity index, which treats all species equally, irrespective of their abundance, in the comparison of species composition between regions although the rare species are assigned the same importance as the dominants.

Both the average and median weed density and weed biomass were fairly high, particularly 
Salonen, J. et al. Weeds in spring cereals in Finland

in organic production and in the unsprayed fields of conventional production. In the early 1980s, the average weed density in unsprayed sample quadrats was 170 plants $\mathrm{m}^{-2}$ (median 124) and the average weed biomass $320 \mathrm{~kg}$ per hectare (median 183) (Salonen 1993). Furthermore, the biomass production of weeds in the 1960s averaged $1000 \mathrm{~kg}$ per hectare (Mukula 1974).

The use of herbicides started to increase in cereal production in Finland in the early 1960s, the peak volume ( $\mathrm{kg}$ active ingredients) being reached in the early 1980s (Hynninen and Blomqvist 1997). Since the 1990s, sulphonylureas have replaced phenoxyacid herbicides to such an extent that the current sprayed area of spring cereals is about the same for both herbicide types. Herbicide treatment in cereal production is still a common practice on conventional farms (Londesborough et al. 2000). Most of the survey farms used the lowest recommended application rate. The main reason for annual interruptions to herbicide application was the unsuitability of weather conditions, either drought or an excess of rain.

Viola arvensis, Fumaria officinalis and $G a$ lium spurium represent species that were common in cereal-dominated production areas in southern Finland but cannot be successfully controlled with sulphonylureas. In general, the intensive manipulation of arable land in favour of crops has also favoured species such as Elymus repens and Viola arvensis, which can adapt to the strong competition in cereal stands.

In organic farming Chenopodium album, Stellaria media, Galeopsis spp. and Viola arvensis were found in more than $90 \%$ of fields studied. The majority of Finnish organic farms converted from conventional to organic cropping after 1995, when Finland became a member of the European Union. Therefore, the botanical composition of fields is still in the process of changing. However, in terms of species diversity, even the short period of organic farming has already been beneficial. Not only did the organic fields have a higher number of weed species but the sprayed conventional and organic fields differed in the most frequent species. Use of herbicides has been found to reduce the number of species in weed communities (Hyvönen and Salonen 2002).

In general, farmers should consider some kind of weed control during the growing season, as the weed infestation on organic farms was fairly high and hardly any direct control measures were carried out. Particularly, perennial weed species such as Elymus repens, Sonchus arvensis and Cirsium arvense may threaten the future of organic cereal production if their control is not given due consideration in crop rotation. Of interest is that these perennial species were not particularly common in a recent Swedish survey of organic farms (Rydberg and Milberg 2000).

Taking into consideration the frequency and biomass production of weed species, Elymus repens is by far the most harmful weed species for spring cereals in Finland. Glyphosate is one of the best selling herbicides in this country (Londesborough et al. 2000) but the conditions for spraying are often unsuitable and its efficacy on E. repens is seldom optimal as it is mostly applied on stubble after harvest in September.

In conclusion, economy was the driving force in the decision-making of crop production in the 1990s. Indirectly, this is reflected in weed floras now that organic farming has become a common practice and the inputs for cereal production are judiciously considered in conventional farming, too. The decrease in cropping intensity gives weeds an opportunity to make a comeback.

Acknowledgements. The weed survey was part of the Finnish Biodiversity Programme's (FIBRE) project "Biodiversity in agricultural environments" coordinated by Dr. Juha Tiainen. FIBRE is a comprehensive six-year research programme launched in Finland in 1997 (see Walls et al. 1999). We thank farmers who allowed us to visit their fields and provided us with information about their farming practices. Our permanent survey staff, Eira-Maija Tanni, Anne Muotila and Riina Paju, and a team of field assistants are acknowledged for their intensive toil. Constructive remarks from two anonymous referees are acknowledged. The survey was financed by MTT Agrifood Research Finland and the Ministry of Agriculture and Forestry. 
Alatalo, R.V. 1981. Problems in the measurement of evenness in ecology. Oikos 37: 199-204.

Albrecht, H. 1995. Changes in arable weed flora of Germany during the last five decades. In: Challenges for weed science in a changing Europe. Proceedings of the $9^{\text {th }}$ EWRS Symposium, Budapest. p. 4148.

Andreasen, C., Streibig, J.C. \& Haas, H. 1991. Soil properties affecting the weed distribution of 37 weed species in Danish fields. Weed Research 31: 181-187.

-, Stryhn, H. \& Streibig. J.C. 1996. Decline of the flora in Danish arable fields. Journal of Applied Ecology 33: 619-626.

Bàrberi, P., Silvestri, N. \& Bonari, E. 1997. Weed communities of winter wheat as influenced by input level and rotation. Weed Research 37: 301-313.

Bayer 1992. Important Crops of the world and their weeds. $2^{\text {nd }}$ ed. BAYER AG, Leverkusen. $1682 \mathrm{p}$.

Becker, B. \& Hurle, K. 1998. Unkrautflora auf Feldern mit unterschiedlich langer ökologischer Bewirtschaftung. Zeitschrift für Pflanzenkrankheiten und Pflanzenschutz, Sonderheft XVI: 155-161.

Chancellor, R.J. \& Froud-Williams, R.J. 1984. A second survey of cereal weeds in central southern England. Weed Research 24: 29-36.

Doucet, C., Weaver, S.E., Hamill, A.S. \& Zhang, J. 1999. Separating the effects of crop rotation from weed management on weed density and diversity. Weed Science 47: 729-735.

Elonen, P. 1983. Plant production research in Finland. Annales Agriculturae Fenniae 22: 258-263.

Erviö, L.-R. \& Salonen, J. 1987. Changes in the weed population of spring cereals in Finland. Annales Agriculturae Fenniae 26: 210-226.

Erviö, R., Hyvärinen, S., Erviö, L.-R. \& Salonen, J. 1994. Soil properties affecting weed distribution in spring cereal and vegetable fields. Agricultural Science in Finland 3: 497-504.

Haas, H. \& Streibig, J.C. 1982. Changing patterns of weed distribution as a result of herbicide use and other agronomic factors. In: LeBaron, H.M. \& Gressel, J. (eds.). Herbicide resistance in plants. J. Wiley \& Sons. p. 57-79.

Hald, A.B. 1999. Weed vegetation (wild flora) of long established organic versus conventional cereal fields in Denmark. Annals of Applied Biology 14: 307-314.

Hämet-Ahti, L., Suominen, J., Ulvinen, T. \& Uotila, P. 1998. Retkeilykasvio (Field Flora of Finland). Finnish Museum of Natural History, Botanical Museum. Helsinki. 656 p.

Heck, K.L.J., van Belle, G. \& Simberloff, D. 1975. Explicit calculation of the rarefaction diversity measurement and the determination of sufficient sample size. Ecology 56: 1459-1461.
Hynninen, E.-L. \& Blomqvist, H. 1997. Pesticide sales continue to slide as planned. Kemia - Kemi 24: 514517.

Hyvönen, T. \& Salonen, J. 2002. Weed species diversity and community composition in cropping practices at two intensity levels - a six-year experiment. Plant Ecology (in press).

Jaccard, P. 1912. The distribution of the flora of the alpine zone. New Phytologist 11: 37-50.

Krebs, C.J. 1999. Ecological Methodology. Second Edition. Benjamin/Cummins, California. $620 \mathrm{p}$.

Légère, A. \& Derksen, D.A. 2000. Is diversity a useful concept for weed management. Proceedings of the XIth International Conference on Weeds. Dijon, France. p. 407-414.

Londesborough, S., Hynninen, E.-L. \& Blomqvist, H. 2000. Pesticide sales in Finland in 1999. Kemia - Kemi27: 492-494.

Ministry of Agriculture and Forestry 1999. Agriculture in Finland. $35 \mathrm{p}$.

Mukula, J. 1974. Weed competition in spring cereals in Finland. Forskning och fors $\varnothing k$ i landbruket 25: 585592.

-, Raatikainen, M., Lallukka, R. \& Raatikainen, T. 1969. Composition of weed flora in spring cereals in Finland. Annales Agriculturae Fenniae 8: 59-109.

- \& Rantanen, O. 1987. Climatic risks to the yield and quality of field crops in Finland. I. Basic facts about Finnish field crops production. Annales Agriculturae Fenniae 26: 1-18.

Raatikainen, M. \& Raatikainen, T. 1975. Heinänurmien sato, kasvilajikoostumus ja sen muutokset. Summary: Yield, composition and dynamics of flora in grassland for hay in Finland. Annales Agriculturae Fenniae 14: 57-191.

Rydberg, N.T. \& Milberg, P. 2000. A survey of weeds in organic farming in Sweden. Biological Agriculture and Horticulture 18: 175-185.

Salonen, J. 1993. Weed infestation and factors affecting weed incidence in spring cereals in Finland - a multivariate approach. Agricultural Science in Finland 2: 525-536.

Sutcliffe, O.L. \& Kay, Q.O.N. 2000. Changes in the arable flora of central southern England since the 1960s. Biological Conservation 93: 1-8.

Tóth, Á., Benécs-Bárdi, G. \& Balzás, G. 1999. Results of national weed surveys in arable land during the past 50 years in Hungary. Proceedings The 1999 Brighton Conference - Weeds. Brighton, UK. p. 805-810.

Walls, M., Vieno, M. \& Peltola, E. (eds.). 1999. The Finnish Biodiversity Research Programme FIBRE. From species to society - the many faces of biodiversity. 1997-1999 Progress report. Publications of the Academy of Finland 6/99. 95 p. 
Salonen, J. et al. Weeds in spring cereals in Finland

\title{
SELOSTUS
}

\section{Kolmas kevätviljapeltojen rikkakasvikartoitus}

\author{
Jukka Salonen, Terho Hyvönen ja Heikki Jalli \\ MTT (Maa- ja elintarviketalouden tutkimuskeskus)
}

Kevätviljapeltojen rikkakasvillisuutta kartoitettiin Etelä- ja Keski-Suomessa vuosina 1997-1999 yhteensä 16 tutkimusalueella. Aineistoa kerättiin tavanomaisesti ja luonnonmukaisesti viljellyiltä pelloilta. Tutkimuksessa oli mukana yhteensä 690 peltoa. Rikkakasvien tiheys laskettiin kymmeneltä ja kuivapaino määritettiin neljältä $0,1 \mathrm{~m}^{2}(40 \times 25 \mathrm{~cm})$ laskentaruudulta. Pienet laskentaruudut olivat osa $1,0 \mathrm{~m}^{2}$ näytealaa, jolta havainnoitiin lajien esiintyminen $0 / 1$-asteikolla. Näytteet kerättiin heinäkuun puolivälin ja elokuun alkupuolen välisenä aikana. Vastaavat kartoitukset on tehty 1960- ja 1980-luvun alussa.

Kevätviljapelloilta löydettiin yhteensä 188 rikkakasvilajia $\left(1,0 \mathrm{~m}^{2}\right.$ havaintoalat). Varsinaisilta näytealoilta $\left(0,1 \mathrm{~m}^{2}\right)$ löytyi 160 kasvilajia, joista 134 oli leveälehtisiä ja 26 heinämäisiä rikkakasveja. Tavanomaisesti viljeltyjen torjunta-aineilla ruiskutettujen peltojen yleisimmät rikkakasvit olivat pelto-orvokki (81\% tutkituista pelloista), pihatähtimö (65\%), pillikkeet (60\%), jauhosavikka (53\%), linnunkaali $(52 \%)$ ja pihatatar $(50 \%)$. Luonnonmukaisesti viljeltyjen peltojen yleisimmät lajit olivat puolestaan jauhosavikka (96\%), pihatähtimö (95\%), pillikkeet (93\%), pelto-orvokki (93\%), peltohatikka (83\%) ja peltoukonnauris $(82 \%)$. Yleisin heinämäinen rikkakasvi oli juolavehnä, jota tavattiin $60 \%$ tavanomaisen viljelyn pelloista ja $81 \%$ luomupelloista. Kaikkiaan 18 rikkakasvilajia oli sellaisia, joita löydettiin vähintään joka kolmannelta tutkitulta pellolta. Kes- kimääräinen lajimäärä kaikilla pelloilla oli 18. Luonnonmukaisesti viljellyillä pelloilla keskimääräinen lajimäärä oli 24 ja tavanomaisesti viljellyillä 16 (ruiskutetuilla 15 ja ruiskuttamattomilla 25 ).

Ruiskutetuilla tavanomaisen viljelyn pelloilla kasvoi rikkakasveja keskimäärin $136 \mathrm{kpl} / \mathrm{m}^{2}$, ruiskuttamattomilla $420 \mathrm{kpl} / \mathrm{m}^{2}$ ja luonnonmukaisesti viljellyillä pelloilla $469 \mathrm{kpl} / \mathrm{m}^{2}$. Rikkakasvien tuottama biomassa oli vastaavasti $163 \mathrm{~kg} / \mathrm{ha}, 605 \mathrm{~kg} / \mathrm{ha} \mathrm{ja} 678$ $\mathrm{kg} / \mathrm{ha}$. Rikkakasvien osuus kevätviljapeltojen kasvimassasta (vilja + rikkakasvit) oli ruiskutetuilla tavanomaisen viljelyn pelloilla keskimäärin $3 \%$ ja luomupelloilla $17 \%$. Juolavehnä tuotti eniten biomassaa.

Rikkakasveja kasvoi viljapelloilla runsaammin kuin 1980-luvun alussa, jolloin edellinen kartoitus tehtiin. Yleisimmät rikkakasvit ovat tavanomaisessa viljelyssä pääosin samoja lajeja kuin 1980-luvulla, mutta esim. juolavehnä on yleistynyt ja runsastunut. Tavanomaisessa viljelyssä on kymmenen yleisimmän lajin joukossa mm. pelto-orvokki, pihatatar, peltomatara ja peltoemäkki, joiden kemiallinen torjunta vaatii erikoisaineita. Luonnonmukaisen viljelyn yleistymisen myötä pelloille näyttävät palaavan sellaiset lajit kuin peltohatikka ja peltoukonnauris sekä kestorikkakasveista peltovalvatti ja pelto-ohdake, jotka tavanomaisessa viljelyssä saadaan pidettyä kurissa kemiallisella torjunnalla ja viljan kilpailukyvyllä. Viljelyn voimaperäisyys tulee vaikuttamaan rikkakasvillisuuden tulevaan kehitykseen. 


\section{AGRICULTURAL AND FOOD SCIENCE IN FINLAND}

\section{Appendix 1}

Frequency ( $\%$ in parentheses) of additional weed species found by region.

Jokioinen (62 fields)

POLVI (24), RANSS (11), PTLAN (8), LIUUT (6), ACHPT (5), SENVU (5), RAPRA (3), BARVU (2), BIDTR (2), FAGES (2), FIIUL (2), RUMLO (2), SONSS (2), TRFPR (2), VICSA (2), VIOPA (2)

\section{Lammi (63 fields)}

VICSS (13), PHLPR (10), ARTVU (8), CHERU (6), STAPA (6), URTDI (6), PTLAN (5), BIDSS (3), LEBAU (3), POATR (3), RUMSS (3), SCRAN (3), ACHPT (2), ALOGE (2), AVEFA (2), CIRVU (2), LINVU (2), MENSS (2), RAPRA (2), SOLTU (2), SONAS (2), VERSS (2)

\section{Nauvo/Korppoo (40 fields)}

VICSS (28), TRFPR (18), EPHHE (15), BIDTR (10), PHLPR (5), SONAS (5), VERSS (5), ALOMY (3), CENCY (3), CHYLE (3), GERSY (3), LIUUT (3), MATCH (3), POLSS (3), POLVI (3), RUMCR (3), SOLNI (3)

\section{Tammela (53 fields)}

BIDTR (15), URTDI (13), ARTVU (11), ALOGE (9), SCRAN (9), POLVI (8), PTLAN (8), RUMLO (8), AVESA (6), BARVU (6), EPISS (6), HORVS (6), PHLPR (6), RAPRA (6), STAPA (6), VERSS (6), ALOPR (4), CENCY (4), CERAR (4), DECCA (4), LEBAU (4), PIEAB (4), RANSS (4), RUBID (4), SAIPR (4), SAXSS (4), SENVU (4), THCFL (4), VERAG (4), VICSS (4), VIOPA (4), ACHPT (2), AEOPO (2), ALOMY (2), ALSPA (2), ANRSY (2), BIDSS (2), CIRVU (2), EPHHE (2), EPIPA (2), EQUPA (2), FAGES (2), LINVU (2), LIUUT (2), MEDSS (2), POAPR (2), PTEAL (2), RORIS (2), SOLSS (2), SONAS (2), SONOL (2), STEGR (2), VICVI (2)

\section{Laukaa/Toivakka (46 fields)}

HORVS (22), SAIPR (22), ACHPT (13), EPIPA (13), URTDI (13), LEBAU (11), PHLPR (11), CHEPO (9), RUMLO (9), VIOPA (9), RAPRA (7), SCRAN (7), ALOGE (4), AVESA (4), BIDTR (4), BRASS (4), CHERU (4), FESSS (4), POAPR (4), VERAG (4), ACRPL (2), AGSTE (2), ARBTH (2), BARVU (2), BIDRA (2), CHYLE (2), CIRPA (2), FIIUL (2), GALPA (2), GEURI (2), LIUUT (2), MYSMI (2), PIUSI (2), VICSS (2)

\section{Kitee (24 fields)}

SAIPR (33), TRFPR (33), URTDI (33), BIDRA (29), HORVS (25), RANSS (25), RORIS (25), LEBAU (21), EPISS (17), FESPR (17), PHLPR (17), RUMLO (17), VIOPA (17), ALCSS (13), ALOAE (13), ARTVU (13), CIRVU (13), GALUL (13), POASS (13), VERSS (13), VIOTR (13), ACHPT (8), ANKSY (8), CHYLE (8), CLTPA (8), FAGES (8), LINSS (8), PTLNO (8), RAPRA (8),
VERCH (8), ALOPO (4), AGSSS (4), AGSTE (4), ARBTH (4), BARVU (4), BETSS (4), CENCY (4), CIRSS (4), CMPRA (4), DECCA (4), EPIPA (4), KNAAR (4), LYSVU (4), MENAR (4), PIEAB (4), PIUSI (4), PTLAN (4), RUBID (4), SILVU (4), VICSE (4), VICSS (4)

Mikkeli (42 fields)

HORVS (26), ARTVU (21), URTDI (21), RUMLO (12), SAIPR (12), VERSS (12), AGSSS (10), ALOAE (10), EPISS (10), PHLPR (10), PTLNO (10), STAPA (10), TRFPR (10), ACHPT (7), AVESA (7), BIDTR (7), MENSS (7), RORIS (7), VICSS (7), VIOPA (7), ALCSS (5), ANKSY (5), BRSRA (5), CHERU (5), CHYLE (5), EPIPA (5), FESSS (5), RAPRA (5), SOLTU (5), VERAG (5), AEOPO (2), ATXPA (2), BIDRA (2), DECCA (2), EQUSY (2), FESPR (2), GAGSS (2), GALUL (2), LEBAU (2), LINVU (2), MENAR (2), OXAAC (2), PIBSA (2), POAPA (2), POASS (2), POLSS (2), PTLAN (2), PTLER (2), RUBID (2), RUMSS (2), TRZAS (2), VERCH (2), VICHI (2)

Paimio/Tarvasjoki (73 fields)

SONAS (40), PLALA (12), ALOGE (8), BIDTR (8), MYSMI (8), CHYLE (7), CERAR (5), LIUUT (5), POLVI (5), RUMLO (5), TRFPR (5), BRSNN (4), BRSRA (4), CIRPA (4), SCRAN (4), AVESA (3), CHEPO (3), CIRHE (3), EPISS (3), FESSS (3), RANSS (3), RAPRA (3), SAIPR (3), SONOL (3), SONSS (3), ANKSY (1), ANTTI (1), ARTVU (1), ATXPA (1), EPIMO (1), EQUSS (1), EQUSY (1), FESPR (1), FIIUL (1), GALPA (1), HORVS (1), LEBAU (1), LOLSS (1), LTHLI (1), PHLPR (1), PIEAB (1), PIUSI (1), POAPR (1), POGSS (1), POLSS (1), SOLSS (1), STAPA (1), VERAG (1), VICSS (1), VIOPA (1)

Laihia (42 fields)

POAPR (21), AlOGE (7), POATR (7), PHLPR (5), BARVU (2), CIRHE (2), CVPTE (2), DECCA (2), FESSS (2), GEURI (2), PLALA (2), POASS (2), SONAS (2), STAPA (2), TRFPR (2)

Nivala (31 fields)

BARVU (42), PHLPR (26), ALOPR (23), POASS (23), LEBAU (19), DECCA (16), BIDSS (6), BRSRA (6), EPISS (6), ALOGE (3), ARTVU (3), BETSS (3), BIDRA (3), BRASS (3), FESPR (3), FIIUL (3), MENAR (3), POAPR (3), POATR (3), VIOPA (3)

\section{Laitila (51 fields)}

ARTVU (20), AVEFA (16), CHEPO (12), BIDTR (10), CIRVU (8), RAPRA (6), SENVU (6), SONAS (6), ALOGE (4), CIRHE (4), EPIMO (4), GEURI (4), PHLPR (4), PIUSI (4), STASI (4), TRFPR (4), VIOPA (4), AGSTE (2), 
Appendix 1

CONAR (2), FIIUL (2), GALTF (2), LEBAU (2), PLALA (2), RUMLO (2), THLCA (2), URTDI (2), VERAG (2), VIOTR (2)

Nurmijärvi (43 fields)

SONAS (12), CHEPO (9), STAPA (9), ARTVU (7), PHLPR (7), ALOGE (5), BIDTR (5), LEBAU (5), POASS (5), FESPR (2), GALTF (2), LINVU (2), RAPRA (2), SCRAN (2), SENVU (2), URTDI (2)

Vieremä (26 fields)

RORSY (35), PHLPR (27), ACHPT (19), EPIPA (19), AVESA (15), PIEAB (12), RUMLO (12), SAIPR (12), VERSS (12), ALCSS (8), ALOGE (8), BIDTR (8), CHYLE (8), CHYVU (8), LEBAU (8), PIUSI (8), POAPR (8), SONAS (8), VERAG (8), CENCY (4), CIRHE (4), CMPPA (4), EQUSY (4), GEURI (4), HORVS (4), RANAU (4), STAPA (4), STEGR (4), TRFPR (4), URTDI (4), VICSS (4), VIOPA (4)

Kihniö/Parkano (33 fields)

HORVS (42), EPIPA (33), ALOGE (30), SAIPR (21), VIOPA (21), PHLPR (18), RUMLO (18), CIRPA (15), POAPR (12), ARTVU (9), CHYLE (9), PIEAB (9), ACHPT (6), BIDTR (6), PIUSI (6), URTDI (6), AEOPO (3), AGSSS (3), AGSTE (3), AlOPR (3), AVESA (3), CENCY (3), LEBAU (3), RUBID (3), TRFHY (3)

Iitti (35 fields)

TRFPR (20), STAPA (17), PHLPR (11), VICSS (11), CENCY (9), PIUSI (9), ALOGE (6), ARTVU (6), POAPR (6), AGSGI (3), ALOPR (3), BETSS (3), CENJA (3), CHEPO (3), CHERU (3), EPIPA (3), FESOV (3), LEBAU (3), POLSS (3), PTLAN (3), RANSS (3), RAPRA (3), RUMCR (3), RUMSS (3), VERSS (3), VICHI (3), VIOPA (3)

Imatra/Ruokolahti (26 fields)

LEBAU (23), ARTVU (19), PHLPR (19), VICHI (19), ACHPT (15), RAPRA (15), PIUSI (12), ALCSS (8), BIDSS (8), CHERU (8), LINVU (8), MENAR (8), RORIS (8), SCRAN (8), URTDI (8), VIOPA (8), ALOGE (4), ALOPR (4), AVEFA (4), CHEPO (4), CHYLE (4), EPIPA (4), EPISS (4), EROCI (4), GEURI (4), HYPPE (4), LOLPE (4), PIBSA (4), POAPR (4), PTLAN (4), PTLNO (4), RANSS (4), RUMCR (4), RUMSS (4), TRFHY (4), TRFPR (4), VICSS (4)

Key of Bayer code abbreviations:

ACHMI Achillea millefolium, ACHPT Achillea ptarmica, ACHSS Achillea spp., ACRPL Acer platanoides, AEOPO Aegopodium podagraria, AGRRE Elymus repens, AGSSS
Agrostis spp., AGSTE Agrostis capillaris, ALCSS Alchemilla spp., ALOAE Alopecurus aequalis, ALOGE Alopecurus geniculatus, ALOMY Alopecurus myosuroides, ALOPR Alopecurus pratensis, ALSPA Alisma plantago-aquatica, ALUSS Alnus spp., ANKSY Angelica sylvestris, ANRSY Anthriscus sylvestris (silvestris), ANTTI Anthemis tinctoria, ARBTH Arabidopsis thaliana, ARTVU Artemisia vulgaris, ATXPA Atriplex patula, AVEFA Avena fatua, AVESA Avena sativa, BARVU Barbarea vulgaris, BETSS Betula spp., BIDRA Bidens radiata, BIDSS Bidens spp., BIDTR Bidens radiata, BRASS Brachiaria spp., BRSNN Brassica napus L. var. oleifera, BRSRA Brassica rapa, BRSRO Brassica rapa L. ssp. oleifera, CAPBP Capsella bursapastoris, CENCY Centaurea cyanus, CERAR Cerastium arvense, CERFO Cerastium fontanum, CHAAN Epilobium angustifolium, CHEAL Chenopodium album, CHEPO Chenopodium polyspermun, CHESS Chenopodium spp., CHYLE Leucanthemum vulgare, CIRAR Cirsium arvense, CIRHE Cirsium helenioides, CIRPA Cirsium palustre, CIRSS Cirsium spp., CIRVU Cirsium vulgare, CLTPA Callitriche palustris, CMPRA Campanula rapunculoides, DECCA Deschampsia cespitosa, EPHHE Euphorbia helioscopia, EPIMO Epilobium montanum, EPIPA Epilobium palustre, EPISS Epilobium spp., EQUAR Equisetum arvense, EQUPA Equisetum palustre, EQUSS Equisetum spp., EQUSY Equisetum sylvaticum, CHYVU Tanacetum vulgare, ERYCH Erysimum cheiranthoides, FAGES Fagopyrum esculentum, FESPR Festuca pratensis, FESSS Festuca spp., FIIUL Filipendula ulmaria, FUMOF Fumaria officinalis, GAEBI Galeopsis bifida, GAESP Galeopsis speciosa, GAESS Galeopsis spp., GAETE Galeopsis tetrahit, GAGSS Galega spp., GALPA Galium palustre, GALSP Galium spurium, GALSS Galium spp., GALUL Galium uliginosum, GERSY Geranium sylvaticum, GEURI Geum rivale, GNAUL Gnaphalium uligonosum, HORVS Hordeum vulgare, spring barley, IUNBU Juncus bufonius, KNAAR Knautia arvensis, LAMAL Lamium album, LAMPU Lamium purpureum, LAMSS Lamium spp., LAPCO Lapsana communis, LEBAU Leontodon autumnalis, LINSS Linaria spp., LINVU Linaria vulgaris, LIUUT Linum usitatissimum, LOLSS Lolium spp., LTHLI Lathyrus linifolius, LTHPR Lathyrus pratensis, LYSVU Lysimachia vulgaris, MATCH Matricaria chamomilla (recutita), MATIN Tripleurospermum inodorum, MATMT Matricaria matricarioides, MATSS Matricaria spp., MEDSS Medicago spp., MENAR Mentha arvensis, MENSS Mentha spp., MYOAR Myosotis arvensis, MYSMI Myosurus minimus, OXAAC Oxalis acetosella, PHLPR Phleum pratense, PIBSA Pisum sativum L. var. arvense, PIEAB Picea abies, PIUSI Pinus silvestris (= sylvestris), PLALA Plantago lanceolata, PLAMA Plantago major, POAAN Poa annua, POAPA Poa palustris, POAPR Poa pratensis, POASS Poa spp., POATR Poa trivialis, POGSS Polygala spp., POLAV Polygonum aviculare, POLCO Fallopia con- 


\section{Appendix 1}

volvulus, POLHY Persicaria hydropiper, POLLA Persicaria lapathifolium, POLPE Persicaria maculosa, POLSS Polygonum spp., POLVI Bistorta vivipara, PRNPA Prunus padus, PTEAL Pteridium aquilinum, PTLAG Potentilla argentea, PTLAN Potentilla anserina, PTLER Potentilla erecta, PTLNO Potentilla norvegica, RANAC Ranunculus acris, RANRE Ranunculus repens, RANSS Ranunculus spp., RAPRA Raphanus raphanistrum, RORIS Rorippa palustris, RUBID Rubus idaeus, RUMAA Rumex acetosella, RUMAC Rumex acetosa, RUMCR Rumex crispus, RUMLO Rumex longifolius, RUMSS Rumex spp., SAIPR Sagina procumbens, SAXSS Salix spp., SCRAN Scleranthus annuus, SECCE Secale cereale, SENVU Senecio vulgaris, SILVU Silene vulgaris, SOLNI Solanum nigrum, SOLSS Solanum spp., SOLTU Solanum tuberosum, SONAR Sonchus arvensis, SONAS Sonchus asper, SONOL
Sonchus oleraceus, SONSS Sonchus spp., SPRAR Spergula arvensis, STAPA Stachys palustris, STEGR Stellaria graminea, STEHO Stellaria holostea, STEME Stellaria media, TAROF Taraxacum officinale, THCFL Thalictrum flavum L. ssp. flavum, THLAR Thlaspi arvense, TRFPR Trifolium pratense, TRFRE Trifolium repens, TRFSS Trifolium, TRZAS Triticum aestivum, spring wheat, TTTDD Dicot weed species, TTTMM Monocot weed species, TUSFA Tussilago farfara, URTDI Urtica dioica, VERAG Veronica agrestis, VERCH Veronica chamaedrys, VERSE Veronica serpyllifolia, VERSS Veronica spp., VICCR Vicia cracca, VICHI Vicia hirsuta, VICSA Vicia sativa, VICSE Vicia sepium, VICSS Vicia spp., VICVI Vicia villosa ROTH ssp. villosa, VIOAR Viola arvensis, VIOPA Viola palustris, VIOSS Viola spp., VIOTR Viola tricolor L. ssp. tricolor 